\title{
A Novel Nano-sized C0304@C Catalyst Derived from Co-MOF Template for Efficient HgO Removal at Low Temperatures with Outstanding SO2 Resistance
}

\author{
Jiacheng Zhou \\ East China University of Science and Technology \\ Qicheng Shen \\ East China University of Science and Technology \\ Jie Yang \\ East China University of Science and Technology

\section{Muhammad Tariq}

Suzhou Institute of Nano-tech and Nano-Bionics Chinese Academy of Sciences: Chinese Academy of

Sciences Suzhou Institute of Nano-tech and Nano-Bionics

\section{Wei Sun}

Hainan University

\section{Limei Cao}

East China University of Science and Technology

Ji Yang ( $\square$ yangji@ecust.edu.cn )

East China University of Science and Technology https://orcid.org/0000-0002-5209-7436

\section{Research Article}

Keywords: Co304@C, Hg0 removal, MOFs, Sulfur-resistance

Posted Date: April 12th, 2021

DOl: https://doi.org/10.21203/rs.3.rs-360511/v1

License: (c) (1) This work is licensed under a Creative Commons Attribution 4.0 International License. Read Full License

Version of Record: A version of this preprint was published at Environmental Science and Pollution Research on July 28th, 2021. See the published version at https://doi.org/10.1007/s11356-021-15663-y. 
1 A novel nano-sized $\mathrm{Co}_{3} \mathrm{O}_{4} @ \mathrm{C}$ catalyst derived from Co-MOF template

2 for efficient $\mathrm{Hg}^{\mathbf{0}}$ removal at low temperatures with outstanding $\mathrm{SO}_{2}$

3 resistance

4 Jiacheng Zhou ${ }^{a}$, Qicheng Shen ${ }^{a}$, Jie Yang ${ }^{a}$, Muhammad Tariq $^{d}$, Wei Sun ${ }^{b}$, Limei Cao $^{a, c^{*}}$

5 and Ji Yang ${ }^{a, c^{*}}$

$6 \quad{ }^{a}$ School of Resources and Environmental Engineering, State Environmental Protection

7 Key Laboratory of Environmental Risk Assessment and Control on Chemical Process,

8 East China University of Science and Technology, Shanghai 200237, PR China

9 bey Laboratory of Agro-Forestry Environmental Processes and Ecological Regulation of

10 Hainan Province, College of Ecology and Environment, Hainan University, 58 Renmin

11 Road, Haikou 570228, P.R. China

12 'Shanghai Institute of Pollution Control and Ecological Security, Shanghai 200092, P.R.

13 China

14 dDivision of Advanced Nanomaterials, Suzhou Institute of Nano-tech and Nano-bionics,

15 Chinese Academy of Sciences (CAS), Suzhou 215123, China

16

17

18

19

20 *Corresponding author: Tel: +86-21-64251668; Fax: +86-21-64251668

21 E -mail address: caolimei@ecust.deu.cn (Limei Cao), yangji@ecust.edu.cn (Ji Yang) 


\section{Abstract}

$24 \mathrm{Co}_{3} \mathrm{O}_{4}$ is a promising $\mathrm{Hg}^{0}$ removal catalyst for industrial application. Operating 25 temperature and low sulfur resistance are two of the main problems that hinder its industrial 26 application in $\mathrm{Hg}^{0}$ removal. Herein, a metal-organic framework (Co-BDC) was introduced 27 as a sacrificial template to obtain the catalyst nano-sized $\mathrm{Co}_{3} \mathrm{O}_{4} @ \mathrm{C}$ by calcination. Part of 28 the organic ligands carbonized during the calcination. Carbon wrapped $\mathrm{Co}_{3} \mathrm{O}_{4}$ and reduced 29 metal agglomeration. The optimal $\mathrm{Hg}^{0}$ removal temperature of the existing cobalt oxides 30 catalysts was always around $150{ }^{\circ} \mathrm{C}$, but $\mathrm{H}_{2}$-TPR showed that the oxygen atoms on the $31 \mathrm{Co}_{3} \mathrm{O}_{4} @ \mathrm{C}$ were more active than those on commercial $\mathrm{Co}_{3} \mathrm{O}_{4}$, causing the $\mathrm{Hg}^{0}$ removal temperature window of $\mathrm{Co}_{3} \mathrm{O}_{4} @ \mathrm{C}$ to shift to lower temperatures. The $\mathrm{Hg}^{0}$ removal 33 efficiency of $\mathrm{Co}_{3} \mathrm{O}_{4} @ \mathrm{C}$ could reach almost $100 \%$ even at $25{ }^{\circ} \mathrm{C}$. In the meanwhile, $34 \mathrm{Co}_{3} \mathrm{O}_{4} @ \mathrm{C}$ also showed a strong $\mathrm{SO}_{2}$ resistance at ambient temperature. Experimental removal catalyst.

Keywords: $\mathrm{Co}_{3} \mathrm{O}_{4} @ \mathrm{C}, \mathrm{Hg}^{0}$ removal, MOFs, Sulfur-resistance 


\section{Introduction}

44 Power plants are the largest point source of mercury released into the atmosphere. The

45 burning of fossil fuels (primarily coal) is the largest single source of emissions from human

46 sources, accounting for about $45 \%$ of the total anthropogenic emissions.(Pacyna et al., 2006; Ji et al., 2018; Zhang et al., 2020b) Nowadays, injecting activated carbon is the most mature technology for $\mathrm{Hg}^{0}$ removal and has been employed by many coal-fired power

49 plants.(Bisson and $\mathrm{Xu}, 2015$; Xu et al., 2018) Activated carbon can adsorb $\mathrm{Hg}^{0}$, but its low

50 efficiency leads to high operation costs.(Cao et al., 2017) Therefore, the desire for more

51 efficient and low-cost $\mathrm{Hg}^{0}$ removal agents has focused research on catalysts.

52 Transition metal oxide $\mathrm{Co}_{3} \mathrm{O}_{4}$ has proved to have good $\mathrm{Hg}^{0}$ oxidation 53 performance.(Zhang et al., 2019a; Yang et al., 2020) It's a promising non-noble metal 54 catalyst for $\mathrm{Hg}^{0}$ removal. It can remove mercury efficiently at high temperatures, and it is 55 more economical than precious metal catalysts. However, it is not easy for $\mathrm{Co}_{3} \mathrm{O}_{4}$ to 56 achieve industrial applications. It is well known that the performance of the catalyst was 57 always affected by temperature. Previous studies have shown that only in a specific 58 temperature range can $\mathrm{Co}_{3} \mathrm{O}_{4}$ reach its best state for $\mathrm{Hg}^{0}$ oxidation. For instance, the cobalt 59 oxide loaded magnetosphere catalyst reported by Yang et al. had its best $\mathrm{Hg}^{0}$ removal

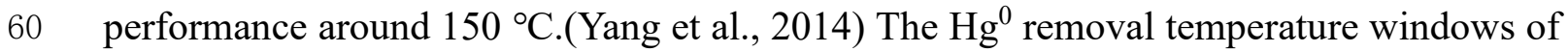
61 the $\mathrm{Ce}-\mathrm{Co}$ catalyst and $\mathrm{Co}_{3} \mathrm{O}_{4}$ nanorods synthesized by $\mathrm{He}$ et al. were $150-350{ }^{\circ} \mathrm{C}$ and 100 $62300{ }^{\circ} \mathrm{C}$, respectively.(Zhang et al., 2017; Zhang et al., 2019b) Therefore, users need to 63 create a specific temperature environment for $\mathrm{Co}_{3} \mathrm{O}_{4}$ to achieve its best performance. In the 64 meanwhile, the internal environment of the flue gas purification system was complicated.

65 The flue gas contained various chemical substances, such as $\mathrm{SO}_{2}, \mathrm{NO}_{\mathrm{x}}$, and so on. It is 
inappropriate to put $\mathrm{Co}_{3} \mathrm{O}_{4}$ in front of Wet Flue Gas Desulfurization(WFGD) equipment

67 because of the existence of $\mathrm{SO}_{2}$, which can inactivate $\mathrm{Co}_{3} \mathrm{O}_{4}$. (Yang et al., 2015) $\mathrm{Co}_{3} \mathrm{O}_{4}$

68 showed low $\mathrm{SO}_{2}$ resistance at high temperatures, so it needs to ensure the catalyst does not

69 come into contact with $\mathrm{SO}_{2}$, which is complicated to operate and uneconomical. If $\mathrm{Co}_{3} \mathrm{O}_{4}$

70 is placed after the WFGD equipment, the flue gas needs to be reheated to meet the

71 temperature requirement of $\mathrm{Co}_{3} \mathrm{O}_{4}$ because the temperature of the WFGD outlet airflow

72 can usually drop to around $45^{\circ} \mathrm{C}$.(Cheng et al., 2020) Given the above, if $\mathrm{Co}_{3} \mathrm{O}_{4}$ can oxidize

$73 \mathrm{Hg}^{0}$ efficiently at low temperatures and have good $\mathrm{SO}_{2}$ resistance, it will be a promising

$74 \quad \mathrm{Hg}^{0}$ removal agent for large-scale applications.

75 In the present work, a 2D MOFs Co-BDC was used as the sacrificial template, and

$76 \mathrm{Co}_{3} \mathrm{O}_{4} @ \mathrm{C}$ was formed by burning it at $500{ }^{\circ} \mathrm{C}$.(Dai et al., 2017) Metal-organic frameworks

77 (MOFs) are a series of novel porous materials with regular pores and large surface area,

78 which consists of metal ions and organic ligands.(Shekhah et al., 2011) It is a promising

79 precursor of nano-sized metal oxides.(Tao et al., 2018) In MOFs, metal clusters are

80 connected by organic ligands. Organic ligands can hinder the agglomeration of metal ions

81 to a certain extent during the calcination process. It can change the particle size of $\mathrm{Co}_{3} \mathrm{O}_{4}$

82 and increase the number of low-coordination atoms located at the edges and corners, which

83 can improve the $\mathrm{Hg}^{0}$ removal performance of the catalyst.(Li et al., 2017a) The

84 experimental results indicated that the temperature window of $\mathrm{Co}_{3} \mathrm{O}_{4} @ \mathrm{C}$ shifted to a low-

85 temperature range. It can remove $\mathrm{Hg}^{0}$ efficiently even at room temperature. Meanwhile, it

86 showed strong $\mathrm{SO}_{2}$ resistance at ambient temperature. Experimental results and

87 characterization proved that $\mathrm{SO}_{2}$ did not compete with $\mathrm{Hg}^{0}$ on the surface of $\mathrm{Co}_{3} \mathrm{O}_{4}$ at low

88 temperatures. On the contrary, it participated in the oxidation of $\mathrm{Hg}^{0}$. This is a great 
89 improvement for $\mathrm{Co}_{3} \mathrm{O}_{4}$ catalyst in $\mathrm{Hg}^{0}$ removal. It reduces the restrictions on the use of

$90 \mathrm{Co}_{3} \mathrm{O}_{4}$, making Co-based catalysts more energy-saving and flexible to combine with the

91 flue gas treatment system.

92

93

94

95

96

97

98

99

100

101

102

103

104

105

106

107

108

109

110

111

\section{Experimental procedure}

\subsection{Materials}

The chemicals used in this study are shown below. Cobalt(II) acetate tetrahydrate $\left(\mathrm{C}_{4} \mathrm{H}_{6} \mathrm{CoO}_{4} \cdot 4 \mathrm{H}_{2} \mathrm{O}, 99.5 \%\right)$ and p-Phthalic acid (PTA, $\left.\mathrm{C}_{8} \mathrm{H}_{6} \mathrm{O}_{4}, 99 \%\right)$ were purchased from Aladdin Industrial Corporation. N,N-Dimethylformamide (DMF, $\mathrm{C}_{3} \mathrm{H}_{7} \mathrm{NO}, 99.5 \%$ ) was purchased from Shanghai Aladdin Biochemical Technology. Ethanol $\left(\mathrm{C}_{2} \mathrm{H}_{5} \mathrm{OH}, \geq 99.7 \%\right)$ was purchased from Shanghai Titan Scientific Co., Ltd. Commercial tricobalt tetraoxide $\left(\mathrm{Co}_{3} \mathrm{O}_{4}, 99.9 \%\right)$ was purchased from Shanghai Macklin Biochemical Co., Ltd. All chemicals purchased from commercial sources were used as received without further purification.

\subsection{Catalyst preparation}

Co-BDC is chosen as the sacrificial template for the form of cobalt oxide nanoparticles (NPs) and Co-BDC was prepared according to previous publication with some changes. Its preparation was carried out as follows: PTA $(0.206 \mathrm{~g}, 1.24 \mathrm{mmol})$ and $\mathrm{C}_{4} \mathrm{H}_{6} \mathrm{CoO}_{4} \cdot 4 \mathrm{H}_{2} \mathrm{O}$ (0.612 $\mathrm{g}, 2.46 \mathrm{mmol})$ were dissolved in $15 \mathrm{~mL}$ of DMF and stirred for $30 \mathrm{~min}$. Then the solution was transferred into a $50 \mathrm{~mL}$ Teflon-lined pressure vessel and heated in the oven at $110^{\circ} \mathrm{C}$ for $24 \mathrm{~h}$. After cooling to room temperature, the purple solid product was washed and sonicated with DMF $(3 \times 30 \mathrm{~mL})$ and fresh ethanol $(3 \times 30 \mathrm{~mL})$ to remove the unwanted particles and unreacted reactants. Finally, the obtained powder was dried at $70{ }^{\circ} \mathrm{C}$ overnight to gain the sacrificial template $\mathrm{Co}-\mathrm{BDC}$ and then $\mathrm{Co}_{3} \mathrm{O}_{4} @ \mathrm{C}$ was prepared by calcining Co- 
$112 \mathrm{BDC}$ at $400 / 500 / 600{ }^{\circ} \mathrm{C}$ for $3 \mathrm{~h}$ in an oven.

$113 \quad 2.3$ Characterization

114 The properties of the samples were characterized and analyzed. The crystal structures of 115 samples were characterized by powder X-ray diffraction (XRD) with a D/max2550V 116 apparatus, $\mathrm{Cu}-\mathrm{Ka}$ radiation source $(\lambda=1.5406 \AA)$ as the $\mathrm{X}$-ray source and its scanning angle 117 of the samples was ranged from $5^{\circ}$ to $75^{\circ}$. The surface area and pore properties of the 118 samples were measured by the Brunauer-Emmett-Teller (BET) method with an apparatus 119 (Micromeritics Tristar 3020 SIN 993). The composition data of the samples was given by 120 a Falion 60S energy dispersive X-ray (EDX) spectrometer. The morphologies of the 121 samples were observed by a scanning electron microscope (SEM) S-3400N. A JEM-2100 122 transmission Electron Microscopy (TEM) was used to observe the morphology and lattice 123 of the samples. The sample's Fourier transform infrared spectroscopy (FT-IR) was 124 measured by Thermo Nicolet iS10. The surface elemental state changes of the samples 125 before and after $\mathrm{Hg}^{0}$ removal were determined via X-ray photoelectron spectroscopy 126 analysis (XPS) using an ESCALAB 250Xi apparatus with an Al-Ka radiation source at an 127 energy step size of $0.05 \mathrm{eV} . \mathrm{H}_{2}$-Temperature programmed reduction $\left(\mathrm{H}_{2}\right.$-TPR $)$ was 128 performed using an Autochem II2920. The temperature range explored was from $50{ }^{\circ} \mathrm{C}$ to $129600{ }^{\circ} \mathrm{C}$ with a heating rate of $10^{\circ} \mathrm{C} / \mathrm{min}$.

$130 \quad 2.4$ Experimental apparatus and procedure

131 A specific experimental system was set up for testing the $\mathrm{Hg}^{0}$ capture ability of the catalyst, 132 as shown in our previous studies(Zhou et al., 2019). In a test, $50 \mathrm{mg}$ of a sample was placed 133 in a quartz tube with an inner diameter of $6 \mathrm{~mm}$ and fixed with quartz wools. The quartz 134 tube contacted the temperature measuring rod of the fixed bed reactor and it can adjust the 
135 temperature of the sample. The $\mathrm{Hg}^{0}$ concentration of the inlet gas was controlled by a water

136 bath and it was $400 \mu \mathrm{g} / \mathrm{m}^{3}$. The $\mathrm{Hg}^{0}$ concentrations of the inlet and outlet gas were

137 measured by the $\mathrm{Hg}^{0}$ vapor analyzer (SG-921, Jiangsu Jiangfen Electroanalytical

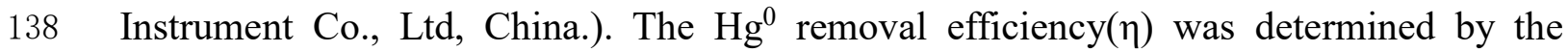

139 following equation:

$$
\eta=\left(\frac{C_{0}-C}{C_{0}}\right) \times 100
$$

141 where $\mathrm{C}_{0}$ and $\mathrm{C}$ are the $\mathrm{Hg}^{0}$ concentration of inlet gas and outlet gas, respectively.

142 The total gas flow was $100 \mathrm{ml} / \mathrm{min}$ and the height of the sample was $10 \mathrm{~mm}$, resulting

143 in a Gas hourly space velocity of $3.06 \times 10^{4} \mathrm{~h}^{-1}$.The temperature-programmed desorption

144 of $\mathrm{Hg}^{0}$ (Hg-TPD) was used to investigate the catalyst performance and its regeneration

145 temperature. The $\mathrm{N}_{2}$ or air flow rate was $100 \mathrm{ml} / \mathrm{min}$. All the samples were heated from 50

146 to $350{ }^{\circ} \mathrm{C}$ and the heating rate was $1^{\circ} \mathrm{C} / \mathrm{min}$.

\section{3. Results and discussion}

$148 \quad 3.1 \mathrm{Hg}^{0}$ removal performance of $\mathrm{Co}_{3} \mathrm{O}_{4} @ \mathrm{C}$
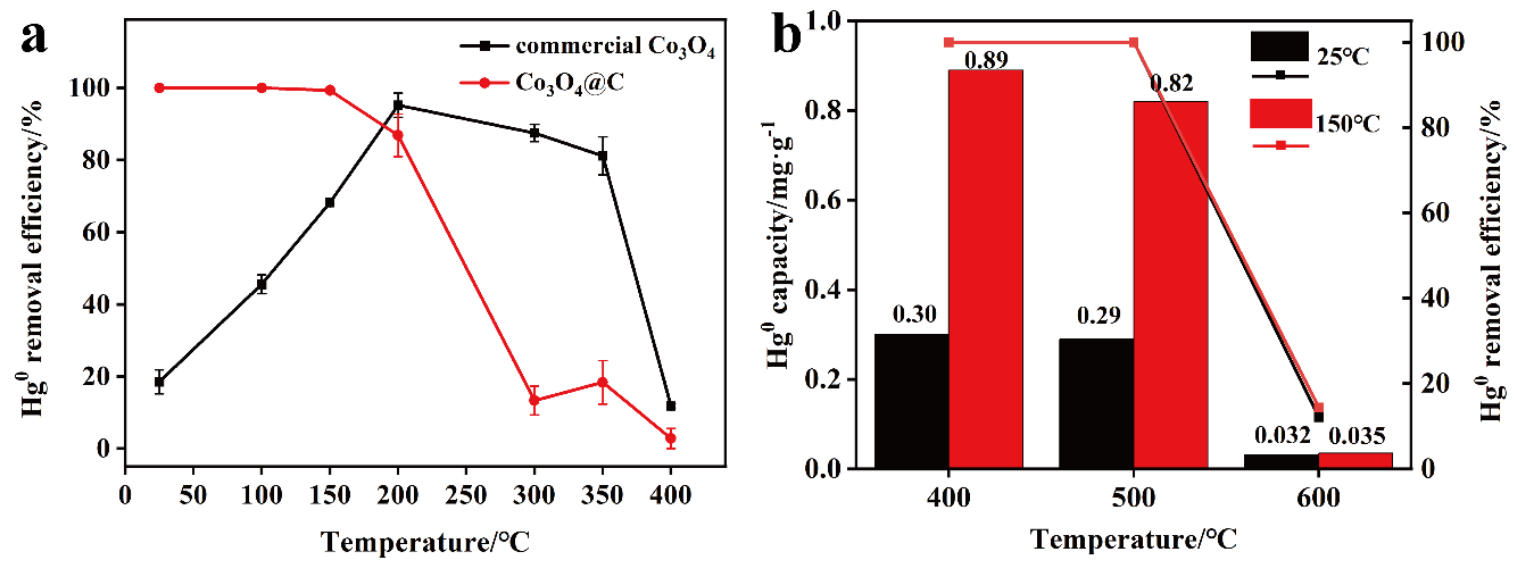

150 Figure 1. (a) Effect of temperature on $\mathrm{Hg}^{0}$ removal performance of commercial $\mathrm{Co}_{3} \mathrm{O}_{4}$ and

$151 \quad \mathrm{Co}_{3} \mathrm{O}_{4} @ \mathbf{C}$; (b) Effect of calcination temperature on $\mathrm{Hg}^{0}$ removal performance of $\mathrm{Co}_{3} \mathrm{O}_{4} @ \mathrm{C}$.

152 Commercial $\mathrm{Co}_{3} \mathrm{O}_{4}$ was introduced to this study to compare $\mathrm{Hg}^{0}$ removal performance with 
$153 \mathrm{Co}_{3} \mathrm{O}_{4} @ \mathrm{C}$. The effect of temperature on the $\mathrm{Hg}^{0}$ removal performance of catalysts was 154 analyzed, as shown in Figure 1a. The experimental results showed that the $\mathrm{Hg}^{0}$ removal 155 temperature window of commercial $\mathrm{Co}_{3} \mathrm{O}_{4}$ and $\mathrm{Co}_{3} \mathrm{O}_{4} @ \mathrm{C}$ was $150{ }^{\circ} \mathrm{C}$ to $350{ }^{\circ} \mathrm{C}$ and $25^{\circ} \mathrm{C}$ 156 to $200{ }^{\circ} \mathrm{C}$ respectively. The $\mathrm{Hg}^{0}$ removal temperature window of $\mathrm{Co}_{3} \mathrm{O}_{4} @ \mathrm{C}$ shifted to a 157 lower temperature region compared to that of commercial $\mathrm{Co}_{3} \mathrm{O}_{4}$. Commercial $\mathrm{Co}_{3} \mathrm{O}_{4} \mathrm{did}$ 158 not perform well in removing $\mathrm{Hg}^{0}$ at ambient temperature $\left(25{ }^{\circ} \mathrm{C} \rightarrow 18.5 \%\right)$. Physical 159 adsorption was considered the major contributor to its $\mathrm{Hg}^{0}$ removal at room temperatures, 160 but its efficiency was low because of the dense structure of commercial $\mathrm{Co}_{3} \mathrm{O}_{4}\left(3.47 \mathrm{~m}^{2} \mathrm{~g}\right.$ $161{ }^{1}$, Table 1).(Yang et al., 2014) When reaction temperature rose, the reactants attained more 162 kinetic energy, thus enhancing the catalytic activity for $\mathrm{Hg}^{0}$ oxidation, resulting in an 163 increase in $\mathrm{Hg}^{0}$ removal performance at high temperatures.(Mochida et al., 2000) 164 Commercial $\mathrm{Co}_{3} \mathrm{O}_{4}$ got its peak efficiency (about 95\%) at $200{ }^{\circ} \mathrm{C}$. However, $\mathrm{Co}_{3} \mathrm{O}_{4} @ \mathrm{C}$ 165 performed much better than Commercial $\mathrm{Co}_{3} \mathrm{O}_{4}$ at low temperatures. It could efficiently 166 remove $\mathrm{Hg}^{0}$ at ambient temperature.

167 The effect of calcination temperature on $\mathrm{Hg}^{0}$ removal performance of $\mathrm{Co}_{3} \mathrm{O}_{4} @ \mathrm{C}$ was 168 studied in the temperature range of 400 to $600{ }^{\circ} \mathrm{C}$. The samples obtained at $400{ }^{\circ} \mathrm{C}$ 169 performed well in mercury removal. Its $\mathrm{Hg}^{0}$ removal efficiency can reach $100 \%$ at 25 and $170150^{\circ} \mathrm{C}$. Its $\mathrm{Hg}^{0}$ removal capacity at 25 and $150{ }^{\circ} \mathrm{C}$ is 0.3 and $0.89 \mathrm{mg} / \mathrm{g}$, respectively. When 171 the calcination temperature increased from $400{ }^{\circ} \mathrm{C}$ to $500{ }^{\circ} \mathrm{C}$, the sample $\mathrm{Co}_{3} \mathrm{O}_{4} @ \mathrm{C}$ 172 maintained excellent $\mathrm{Hg}^{0}$ removal performance. However, when the calcination 173 temperature was increased to $600{ }^{\circ} \mathrm{C}$, the $\mathrm{Hg}^{0}$ removal efficiency of the sample dropped 174 abruptly. The precursor is sintered into larger particles at too high temperature, which is 175 not conducive to the catalytic reaction. The $\mathrm{Hg}^{0}$ removal ability of the sample is closely 
176 related to the appropriate calcination temperature. Accordingly, $500{ }^{\circ} \mathrm{C}$ was chosen as the

177 calcination temperature of $\mathrm{Co}_{3} \mathrm{O}_{4} @ \mathrm{C}$ in this study.

$178 \quad 3.2$ The characterization of $\mathrm{Co}_{3} \mathrm{O}_{4} @ \mathrm{C}$

$179 \mathrm{Co}_{3} \mathrm{O}_{4} @ \mathrm{C}$ showed excellent $\mathrm{Hg}^{0}$ removal efficiency (almost 100\%) at low temperatures.

180 The properties of the catalyst $\mathrm{Co}_{3} \mathrm{O}_{4} @ \mathrm{C}$ depend on its micromorphology, crystal forms, 181 and sizes. The X-ray diffraction (XRD) patterns of $\mathrm{Co}_{3} \mathrm{O}_{4} @ \mathrm{C}$ and commercial $\mathrm{Co}_{3} \mathrm{O}_{4}$ were 182 shown in Figure 2a. They both agree well with simulated $\mathrm{Co}_{3} \mathrm{O}_{4}(\mathrm{PDF} \# 74-2120)$ and the 183 peaks of $\mathrm{Co}_{3} \mathrm{O}_{4} @ \mathrm{C}$ at $19^{\circ}, 31.3^{\circ}, 36.8^{\circ}, 38.5^{\circ}, 44.8^{\circ}, 55.7^{\circ}, 59.4^{\circ}$, and $65.2^{\circ}$ corresponded 184 to the crystal planes (111), (220), (311), (222), (400), (422), (511) and (400) of $\mathrm{Co}_{3} \mathrm{O}_{4}$ 185 respectively(Chen et al., 2019). $\mathrm{Co}_{3} \mathrm{O}_{4}$ was successfully synthesized by the calcination of 186 Co-BDC in $\mathrm{Co}_{3} \mathrm{O}_{4} @ \mathrm{C}$ at $500{ }^{\circ} \mathrm{C}$.

187 The SEM images revealed the microscopic morphology of the sample. Figure 2b-2c 188 showed that $\mathrm{Co}_{3} \mathrm{O}_{4} @ \mathrm{C}$ was made up of nano-sized particles. The $\mathrm{N}_{2}$ adsorption-desorption 189 isotherm of $\mathrm{Co}_{3} \mathrm{O}_{4} @ \mathrm{C}$ is shown in Figure 2d. It is a type IV curve, according to Brunauer190 Deming-Deming-Teller classification, and it exhibited an H3 hysteresis loop which was 191 characteristic of aggregates of plate-like particles. The pore size distribution of the sample 192 (inset Figure 2d) showed that the pore diameter of $\mathrm{Co}_{3} \mathrm{O}_{4} @ \mathrm{C}$ was mainly distributed 193 around $40 \mathrm{~nm}$, indicating the existence of mesopores. The BET surface area of $\mathrm{Co}_{3} \mathrm{O}_{4} @ \mathrm{C}$ 194 was $49.79 \mathrm{~m}^{2} \cdot \mathrm{g}^{-1}$, and its pore volume and pore size (Table 1) was $0.26 \mathrm{~cm}^{3} \cdot \mathrm{g}^{-1}$ and 21.04 $195 \mathrm{~nm}$, respectively. Transmission electron microscopy further analyzed the structure of the 196 sample, as shown in Figure 2e. the sample exhibited an ordered lattice structure, and its 197 interplanar spacing of $0.24 \mathrm{~nm}$ corresponded to $\mathrm{Co}_{3} \mathrm{O}_{4}(311)$. However, there were gray 198 areas without lattice fringes on the edge of the particle, which was considered to be 
amorphous carbon. As seen from the figure, amorphous carbon wrapped the $\mathrm{Co}_{3} \mathrm{O}_{4}$ particle.
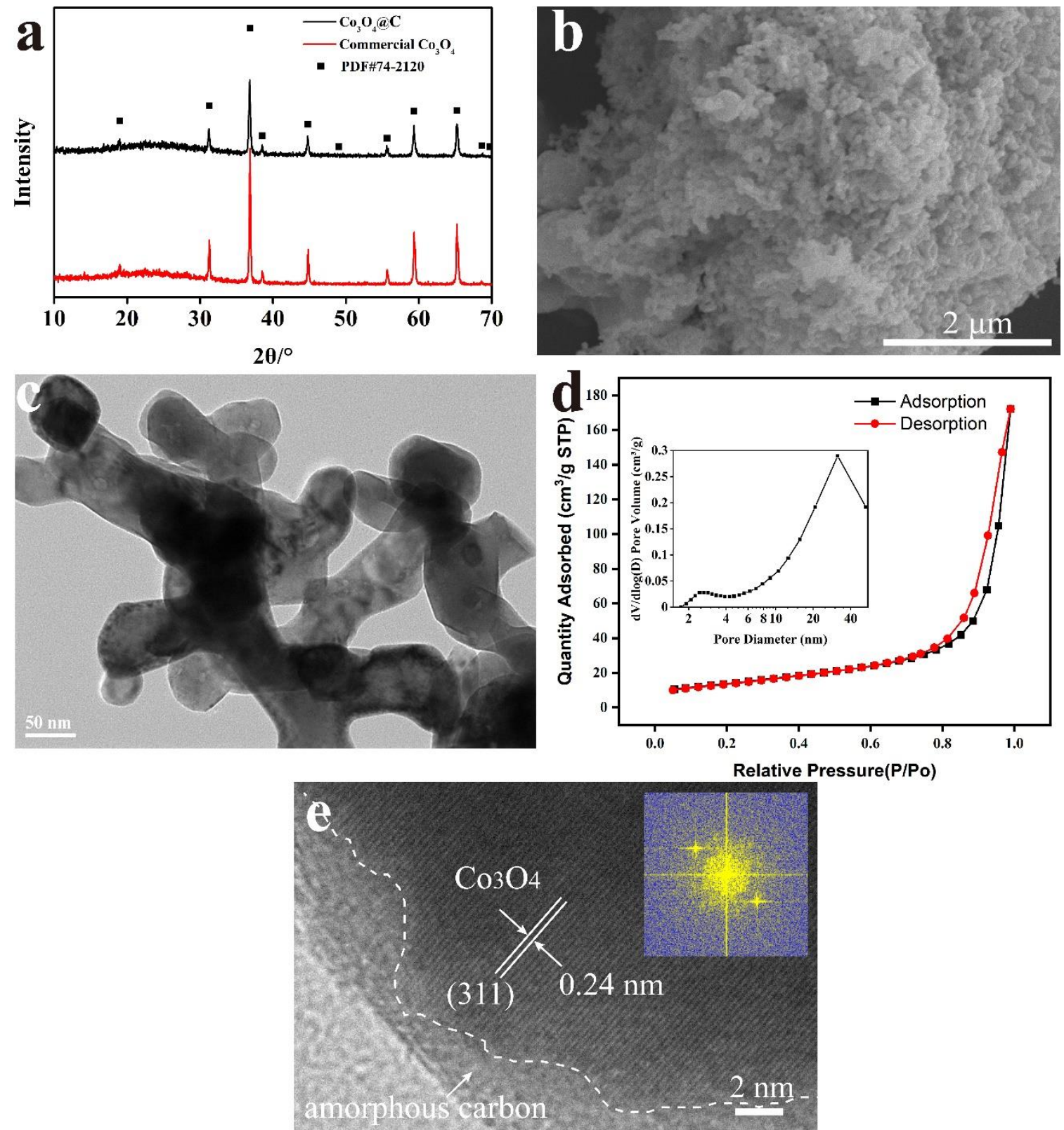

201 Figure 2. The micromorphology of $\mathrm{Co}_{3} \mathrm{O}_{4} @ \mathrm{C}$ powders. (a) XRD patterns of $\mathrm{Co}_{3} \mathrm{O}_{4} @ \mathrm{C}$, 202 commercial $\mathrm{Co}_{3} \mathrm{O}_{4}$, and the simulated $\mathrm{Co}_{3} \mathrm{O}_{4}$ (PDF\#74-2120) (b-c) SEM images of $\mathrm{Co}_{3} \mathrm{O}_{4} @ \mathrm{C}$ 203 powders prepared by the calcination method. (d) $\mathbf{N}_{2}$ adsorption-desorption isotherm of $\mathrm{Co}_{3} \mathrm{O}_{4} @ \mathrm{C}$ and its pore size distribution. Inset shows the pore size distribution of the sample. (e) TEM image of $\mathrm{Co}_{3} \mathrm{O}_{4} @ \mathrm{C}$.

Table 1. Textural properties of $\mathrm{Co}_{3} \mathrm{O}_{4} @ \mathrm{C}$ and commercial $\mathrm{Co}_{3} \mathrm{O}_{4}$ 


\begin{tabular}{|c|c|c|c|c|c|c|}
\hline \multirow[t]{2}{*}{ Catalyst } & \multirow{2}{*}{$\begin{array}{c}\mathrm{S}_{\mathrm{BET}} \\
\left(\mathrm{m}^{2} \cdot \mathrm{g}^{-1}\right)\end{array}$} & \multirow{2}{*}{$\begin{array}{c}\text { Pore size } \\
\text { (nm) }\end{array}$} & \multirow{2}{*}{$\begin{array}{c}\text { Pore volume } \\
\left(\mathrm{cm}^{3} \cdot \mathrm{g}^{-1}\right)\end{array}$} & \multicolumn{3}{|c|}{ Element content (at \%) } \\
\hline & & & & $\mathrm{C}$ & $\mathrm{O}$ & Co \\
\hline $\mathrm{Co}_{3} \mathrm{O}_{4} @ \mathrm{C}$ & 49.79 & 21.04 & 0.26 & 20.3 & 29.1 & 50.6 \\
\hline $\begin{array}{l}\text { Commercial } \\
\qquad \mathrm{Co}_{3} \mathrm{O}_{4}\end{array}$ & 3.47 & 15.11 & 0.013 & 7.9 & 39.9 & 52.2 \\
\hline
\end{tabular}
higher than that of commercial $\mathrm{Co}_{3} \mathrm{O}_{4}(7.9 \%)$. This is because during the calcination 209 process, the organic ligands in MOFs were not completely decomposed, and carbonization 210 occurred. Table 1 showed that the molar ratio of $\mathrm{O}$ to Co content in $\mathrm{Co}_{3} \mathrm{O}_{4} @ \mathrm{C}$ and 211 commercial $\mathrm{Co}_{3} \mathrm{O}_{4}$ was 0.575 and 0.764 , respectively (simulated $\mathrm{Co}_{3} \mathrm{O}_{4}, \mathrm{O}: \mathrm{Co}=0.75$ ). The 212 relative content of element oxygen in $\mathrm{Co}_{3} \mathrm{O}_{4} @ \mathrm{C}$ was less than that of simulated $\mathrm{Co}_{3} \mathrm{O}_{4}$ 213 significantly.

$214 \quad 3.3$ The effect of $\mathrm{O}_{2}$ and temperature
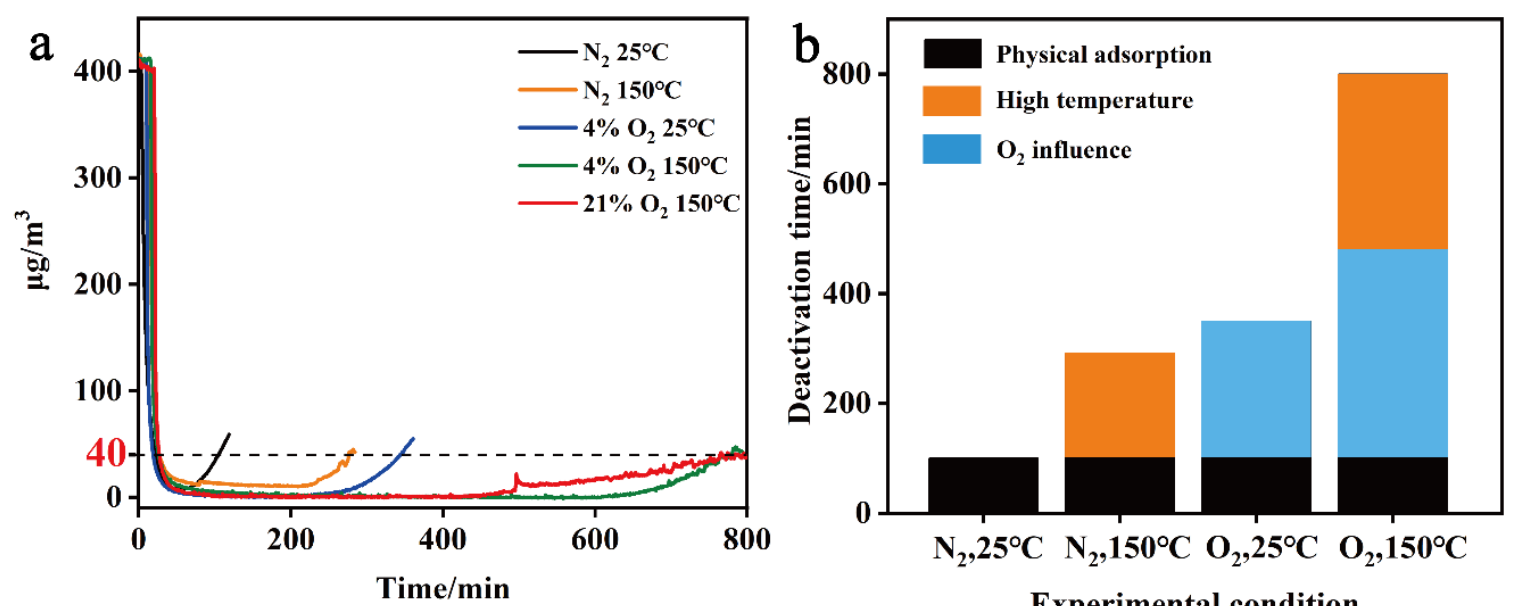

Experimental condition

216 Figure 3. (a) The synergy of temperature and the gas components $\mathbf{O}_{2}$ on $\mathbf{H g}^{\mathbf{0}}$ removal performance of $\mathrm{Co}_{3} \mathrm{O}_{4} @ \mathrm{C}$. (b) The analysis of different experimental conditions on deactivation time of $\mathrm{Co}_{3} \mathrm{O}_{4} @ \mathrm{C}$.

219 The catalytic performance of $\mathrm{Co}_{3} \mathrm{O}_{4} @ \mathrm{C}$ could be greatly improved in the presence of $\mathrm{O}_{2}$, 
220 as shown in Figure 3a. $\mathrm{Co}_{3} \mathrm{O}_{4} @ \mathrm{C}$ performed poorly on $\mathrm{Hg}^{0}$ physical adsorption and lost its 221 activity within $100 \mathrm{~min}$ in pure $\mathrm{N}_{2}$ atmosphere at ambient temperature. However, when $\mathrm{O}_{2}$ 222 was injected into the carrier gas, its deactivation time increased significantly from $100 \mathrm{~min}$ 223 to $350 \mathrm{~min}$ (the blue line). In the meanwhile, it was found that increasing the $\mathrm{O}_{2}$ 224 concentration from $4 \%$ (the green line) to $21 \%$ (the red line) did not improve the $\mathrm{Hg}^{0}$ 225 removal performance of the sample.

226 Temperature also had a great influence on the activity of $\mathrm{Co}_{3} \mathrm{O}_{4} @ \mathrm{C}$. It was found that 227 the $\mathrm{Hg}^{0}$ oxidation activity of $\mathrm{Co}_{3} \mathrm{O}_{4} @ \mathrm{C}$ could also be improved by heating in the absence 228 of $\mathrm{O}_{2}$ (the orange line, in Figure 3a). When the ambient temperature rose from $25{ }^{\circ} \mathrm{C}$ to $229150{ }^{\circ} \mathrm{C}$, the deactivation time of $\mathrm{Co}_{3} \mathrm{O}_{4} @ \mathrm{C}$ was extended by 250 minutes in the $\mathrm{N}_{2}$ 230 atmosphere, as shown in Figure $3 \mathrm{~b}$. Figure $3 \mathrm{~b}$ also exhibited the synergy of temperature 231 and $\mathrm{O}_{2}$ on the $\mathrm{Hg}^{0}$ removal performance. High temperature and $\mathrm{O}_{2}$ could increase the 232 deactivation time by 150 min and 250 min, respectively. However, the sample could 233 maintain its activity within $800 \mathrm{~min}$ when there was $\mathrm{O}_{2}$ in the carrier gas, and the ambient 234 temperature was $150{ }^{\circ} \mathrm{C}$. It extended the deactivation time by 700 minutes, proving the 235 synergistic effect of oxygen and high temperature. 

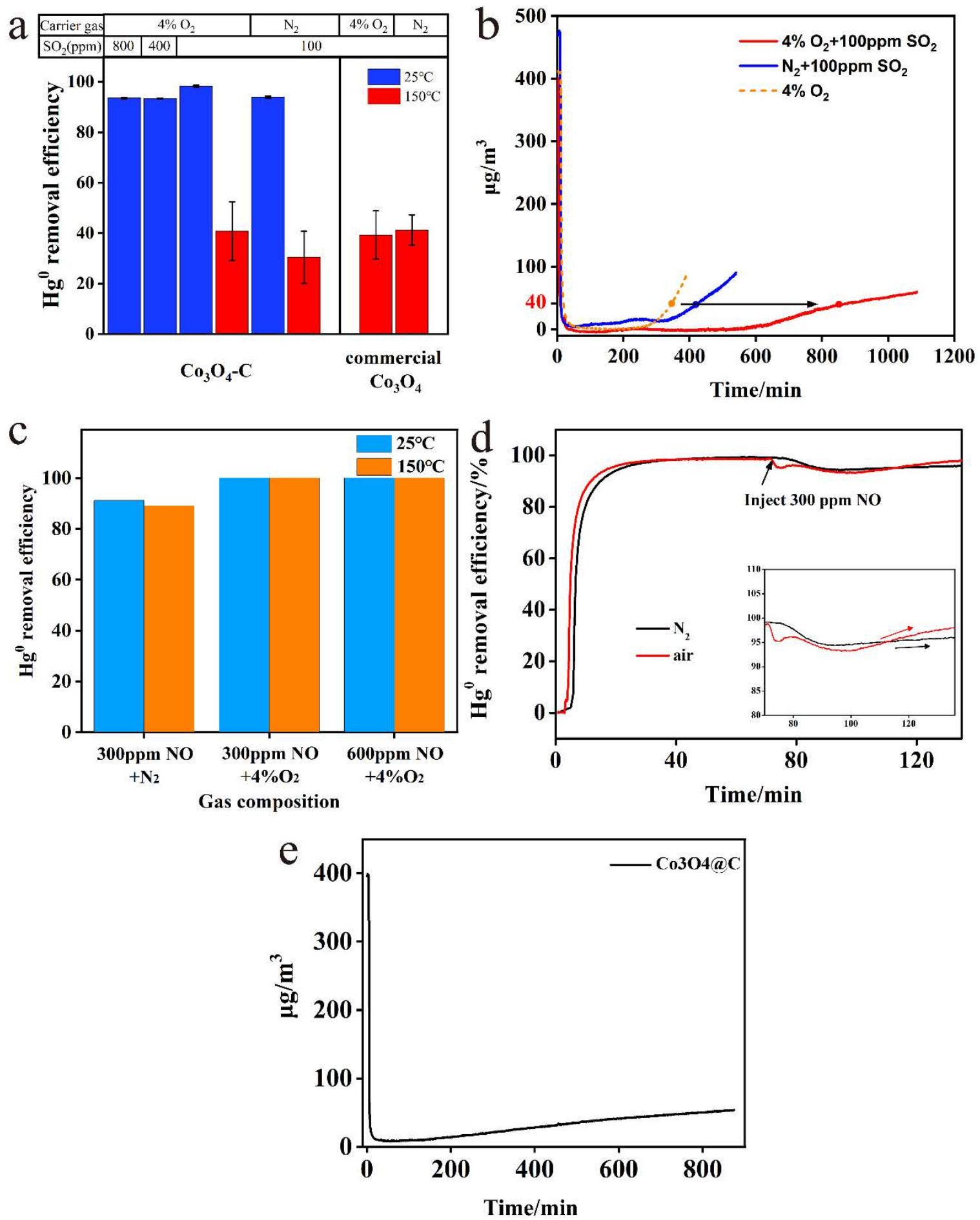

237 Figure 4. (a) Synergistic effect of temperature and $\mathrm{SO}_{\mathbf{2}}$ on $\mathbf{H g}^{\mathbf{0}}$ removal efficiency of the sample.

238 (b) Synergistic effect of $\mathbf{O}_{2}$ and $\mathbf{S O}_{2}$ on the deactivation time of the sample. Experimental 239 conditions: catalyst mass, 50 mg; experimental temperature, $25{ }^{\circ} \mathrm{C}$; gas stream contents, 285 $240 \mathrm{mg} / \mathrm{m}^{3} \mathrm{SO}_{\mathbf{2}}+4 \% \mathrm{O}_{\mathbf{2}} / \mathrm{N}_{\mathbf{2}}$; gas flow rate, $100 \mathrm{~mL} / \mathrm{min}$. (c) the effect of $\mathrm{NO}_{\mathbf{x}}$ on $\mathrm{Hg}^{\mathbf{0}}$ removal efficiency. 
(d) the $\mathrm{Hg0}$ removal performance. (e) The $\mathrm{Hg}^{0}$ removal performance of $\mathrm{Co}_{3} \mathrm{O}_{4} @ \mathrm{C}$ in the simulate gas at ambient temperature. The gas components: $400 \mu \mathrm{g} / \mathrm{m}^{3} \mathrm{Hg}^{0}+4 \% \mathrm{O}_{2}+2286 \mathrm{mg} / \mathrm{m}^{3} \mathrm{SO}_{2}+402$ $\mathbf{m g} / \mathbf{m}^{3} \mathbf{N O}+\mathbf{N}_{2}$

\subsection{The effect of $\mathrm{SO}_{2}$}

The concentration of chemical substances in flue gas is always higher than that of $\mathrm{Hg}^{0}$, and their influence on $\mathrm{Hg}^{0}$ removal is an important index to evaluate the performance of catalysts(Liu, 2008). Many studies indicated that $\mathrm{SO}_{2}$ played the role of inhibitor, which competed with mercury on the surface of metal oxides.(Li et al., 2011; Yang et al., 2011; Zhang et al., 2014) The negative effect of $\mathrm{SO}_{2}$ was also found at high temperatures $\left(150^{\circ} \mathrm{C}\right)$ in this study, as shown in Figure $4 \mathrm{a}$. The $\mathrm{Hg}^{0}$ removal efficiency of commercial $\mathrm{Co}_{3} \mathrm{O}_{4}$ and $\mathrm{Co}_{3} \mathrm{O}_{4} @ \mathrm{C}$ both dropped to about 40\% when $\mathrm{SO}_{2}$ was injected into the carrier gas, and the ambient temperature rose to $150{ }^{\circ} \mathrm{C} . \mathrm{Co}_{3} \mathrm{O}_{4} @ \mathrm{C}$ deactivated as fast as commercial $\mathrm{Co}_{3} \mathrm{O}_{4}$, demonstrating its poor $\mathrm{SO}_{2}$ poisoning resistance at high temperatures as $\mathrm{Co}_{3} \mathrm{O}_{4}$ in the literature.(Yang et al., 2014) Nevertheless, $\mathrm{Co}_{3} \mathrm{O}_{4} @ \mathrm{C}$ showed excellent $\mathrm{SO}_{2}$ resistance at room temperature (the blue part, Figure 3a). Its $\mathrm{Hg}^{0}$ removal efficiency was above $90 \%$ when $\mathrm{SO}_{2}$ was injected into the gas flue, and the increase in $\mathrm{SO}_{2}$ concentration did not reduce the $\mathrm{Hg}^{0}$ removal performance of $\mathrm{Co}_{3} \mathrm{O}_{4} @ \mathrm{C}$. Its $\mathrm{Hg}^{0}$ removal efficiency is maintained at $90 \%$ even in the presence of $2286 \mathrm{mg} / \mathrm{m}^{3} \mathrm{SO}_{2}$. In the meanwhile, the catalyst deactivation experimental results showed that $\mathrm{SO}_{2}$ not only had no negative effects on the sample, but also promoted the removal of $\mathrm{Hg}^{0}$ at ambient temperature, as shown in Figure 4b. The deactivation time of the sample in the $\mathrm{SO}_{2}+\mathrm{N}_{2}$ atmosphere was $430 \mathrm{~min}$, better than that in the $\mathrm{O}_{2}+\mathrm{N}_{2}$ atmosphere $(340 \mathrm{~min})$. The presence of $\mathrm{SO}_{2}$ in the $\mathrm{O}_{2}$ atmosphere can prolong the deactivated time of $\mathrm{Co}_{3} \mathrm{O}_{4} @ \mathrm{C}$ from 340 min to $860 \mathrm{~min}$. In summary, $\mathrm{SO}_{2}$ played a role in promoting $\mathrm{Hg}^{0}$ removal at ambient temperature. 
266 NO can be oxidized by lattice oxygen or adsorbed oxygen on the surface of metal oxide,

267 forming new species like $\mathrm{NO}_{2}$ and $\mathrm{NO}^{+}$, so it might compete with $\mathrm{Hg}^{0}$ and inhibit $\mathrm{Hg}^{0}$ 268 oxidation on the surface of $\mathrm{Co}_{3} \mathrm{O}_{4} @ \mathrm{C}$.(Li et al., 2008) Nevertheless, NO is weakly 269 adsorbed on the surface of metal oxides to form $\mathrm{NO}_{2}$, nitrite, and nitrate species and cannot 270 repel $\mathrm{Hg}^{0}$ from the surface of the catalyst.(Jin et al., 2010; Li et al., 2012) Figure 4c showed 271 that NO slightly inhibited the oxidation of $\mathrm{Hg}^{0}$ removal in the $\mathrm{N}_{2}$ atmosphere. $\mathrm{The}^{\mathrm{H}} \mathrm{C}$ 272 removal efficiency of $\mathrm{Co}_{3} \mathrm{O}_{4} @ \mathrm{C}$ dropped to about $90 \%$ when $402 \mathrm{mg} / \mathrm{m}^{3} \mathrm{NO}$ was injected 273 into $\mathrm{N}_{2}$. However, this negative effect did not appear when the carrier gas contained $\mathrm{O}_{2}$.

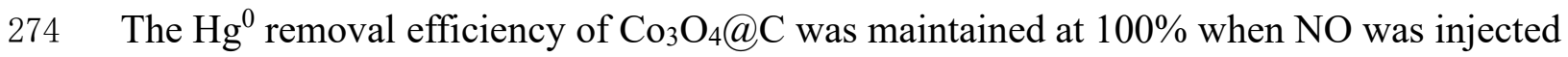
275 into $4 \% \mathrm{O}_{2}$ atmosphere regardless of temperature and $\mathrm{NO}$ concentration changes. Figure $2764 \mathrm{~d}$ showed the real-time change of mercury removal efficiency when NO was injected into 277 the carrier gas. When $402 \mathrm{mg} / \mathrm{m}^{3}$ of $\mathrm{NO}$ was injected into the $\mathrm{N}_{2}$ gas flow, the $\mathrm{Hg}^{0}$ removal 278 efficiency of $\mathrm{Co}_{3} \mathrm{O}_{4} @ \mathrm{C}$ decreased from 99\% to 96\%. NO occupied part of active sites on 279 the surface of the sample and inhibited the $\mathrm{Hg}^{0}$ removal performance of $\mathrm{Co}_{3} \mathrm{O}_{4} @ \mathrm{C}$. The 280 same phenomenon occurred when the gas flow change from $\mathrm{N}_{2}$ to air but the $\mathrm{Hg}^{0}$ removal 281 efficiency of the sample gradually recovered within 60 minutes in the presence of $\mathrm{O}_{2}$, 282 which may be due to the adsorbed NO being oxidized and then reacting with $\mathrm{Hg}^{0}$.

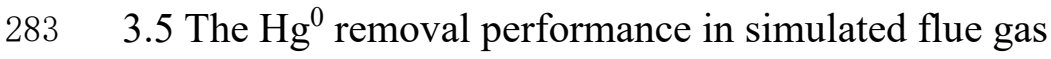

284 It is necessary to test the $\mathrm{Hg}^{0}$ removal capacity of the sample under the simulated flue gas 285 atmosphere to study the comprehensive influence of all kinds of chemical compositions. 286 In this study, the composition of simulated gas was $400 \mu \mathrm{g} / \mathrm{m}^{3} \mathrm{Hg}^{0}+4 \% \mathrm{O}_{2}+2286 \mathrm{mg} / \mathrm{m}^{3}$ $287 \mathrm{SO}_{2}+402 \mathrm{mg} / \mathrm{m}^{3} \mathrm{NO}+\mathrm{N}_{2}$, and $\mathrm{Co}_{3} \mathrm{O}_{4} @ \mathrm{C}$ maintained excellent $\mathrm{Hg}^{0}$ removal efficiency $(>$ 
$90 \%$ ) for about 800 minutes when it was exposed to the gaseous environment where $\mathrm{NO}$,

$289 \mathrm{SO}_{2}$ and $\mathrm{Hg}^{0}$ were present simultaneously, as shown in Figure 4e. It showed great 290 adaptability to the complex simulated flue gas at ambient temperature.

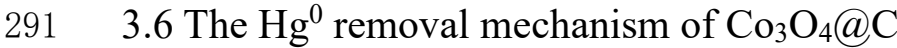

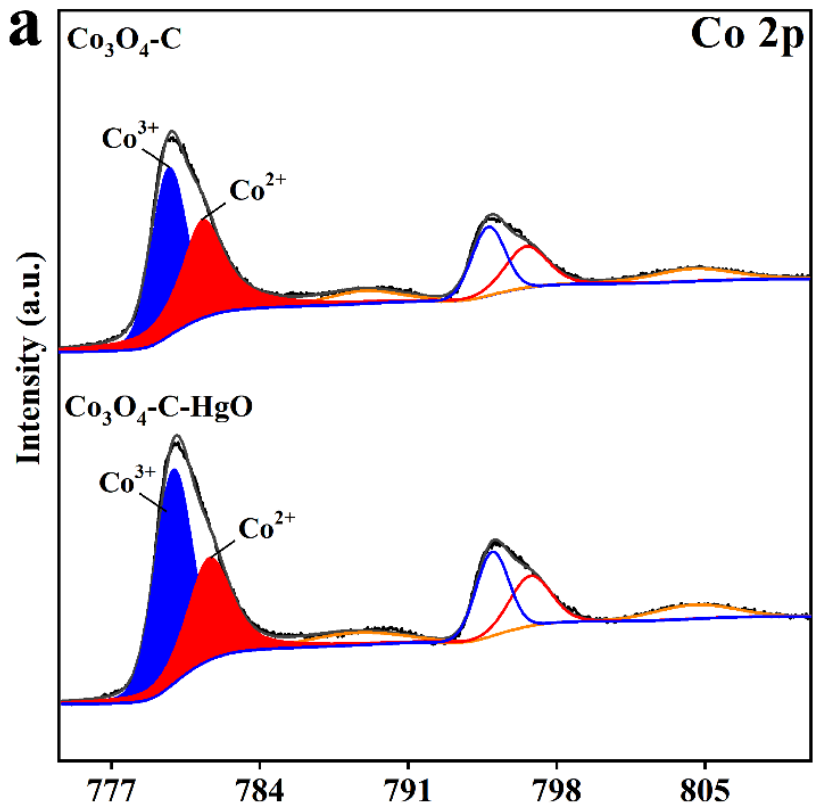

B.E.(eV)
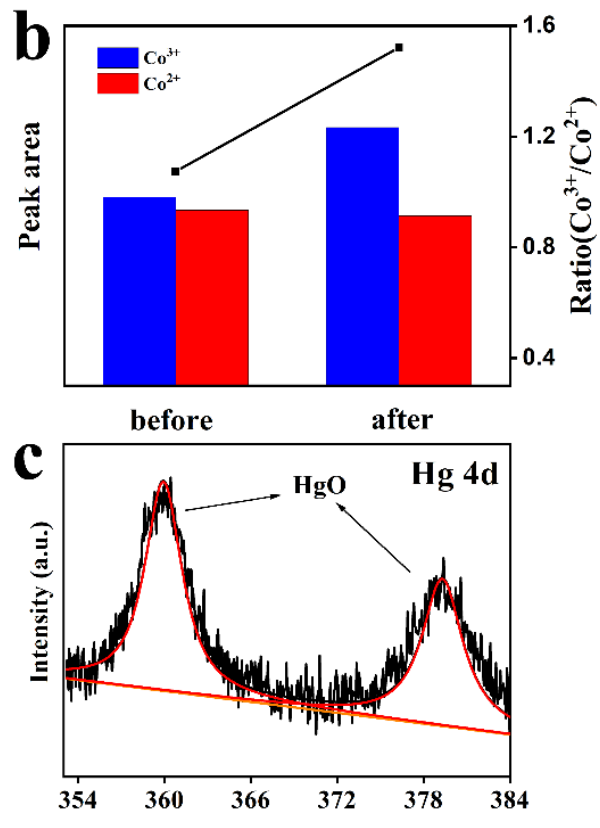

B.E.(eV)
292

293

Figure 5. (a) The Co 2p XPS spectra of $\mathrm{Co}_{3} \mathrm{O}_{4} @ \mathrm{C}$ before and after the treatment; (b) Peak area of $\mathrm{Co} 2 \mathrm{p}$ and the ratio change of $\mathrm{Co}^{3+} / \mathrm{Co}^{2+}$. (c) The $\mathrm{Hg}$ 4d XPS spectra of $\mathrm{Co}_{3} \mathrm{O}_{4} @ \mathrm{C}$ after the treatment.

The structural defects of the lattice stimulated the formation of active surface species that are conducive to $\mathrm{Hg}^{0}$ oxidation(Machida et al., 2008; Hu et al., 2019). As mentioned before, the EDX result showed that the sample $\mathrm{Co}_{3} \mathrm{O}_{4} @ \mathrm{C}$ had a lack of coordination oxygen (molar ratio $\mathrm{O}: \mathrm{Co}=0.575)$, which may be caused by oxygen competition inside the sacrificial template during calcination. The incomplete combustion of organic ligands produced carbon. The carbon wrapped $\mathrm{Co}_{3} \mathrm{O}_{4}$ and robbed the oxygen of the cobalt ions, causing the exposure of the cobalt ions and the lack of lattice oxygen in the structure of $\mathrm{Co}_{3} \mathrm{O}_{4}$. The $\mathrm{Co}$ 
2p XPS spectra of $\mathrm{Co}_{3} \mathrm{O}_{4} @ \mathrm{C}$ before and after the treatment showed in Figure 5a. The 304 binding energies at approximately 794.8, 779.7, 796.8 and 781.6 eV were assigned to $\mathrm{Co}^{3+}$ $3052 \mathrm{p}_{1 / 2}, \mathrm{Co}^{3+} 2 \mathrm{p}_{3 / 2}, \mathrm{Co}^{2+} 2 \mathrm{p}_{1 / 2}$ and $\mathrm{Co}^{2+} 2 \mathrm{p}_{3 / 2}$, respectively.(Wei et al., 2008) During the 306 treatment, the oxygen in the air continuously filled structural defects on the surface of the 307 catalyst and combines with the exposed $\mathrm{Co}$ ions, so that the $\mathrm{Co}^{3+} / \mathrm{Co}^{2+}$ ratio rose from 1.73 308 to 2, as shown in Figure 5b. The lack of lattice oxygen led to a reduction in the valence of 309 cobalt in $\mathrm{Co}_{3} \mathrm{O}_{4} @ \mathrm{C}$. As $\mathrm{Hg}^{0}$ was continuously oxidized on the surface of $\mathrm{Co}_{3} \mathrm{O}_{4} @ \mathrm{C}$, the 310 number of structural defects decreased. When the catalyst was deactivated, it could be seen 311 that the $\mathrm{Co}^{3+} / \mathrm{Co}^{2+}$ ratio was 2, which was the correct ratio of $\mathrm{Co}^{3+}$ to $\mathrm{Co}^{2+}$ in $\mathrm{Co}_{3} \mathrm{O}_{4}$. Thus, 312 the structural defects on the surface of $\mathrm{Co}_{3} \mathrm{O}_{4} @ \mathrm{C}$ were considered to be one of the factors 313 contributing to its outstanding $\mathrm{Hg}^{0}$ performance.

314 Under the synergy of temperature and $\mathrm{O}_{2}$, the $\mathrm{Hg}^{0}$ removal effect of the sample was 315 further improved. As mentioned above, it could be confirmed that both $\mathrm{O}_{2}$ and lattice 316 oxygen on the catalyst surface participated in the oxidation of $\mathrm{Hg}^{0} \cdot \mathrm{HgO}$ was found in the 317 sample after the experiment through an X-ray photoelectron spectroscopy. In Figure 5c, 318 the binding energy of $\mathrm{Hg} 4 \mathrm{~d}_{3 / 2}$ and $\mathrm{Hg} 4 \mathrm{~d}_{5 / 2}$ peaks was 359.9 and $379.3 \mathrm{eV}$, respectively, 319 which matched well with the peak data of $\mathrm{HgO}$ in the NIST XPS database. Thus, it can be 320 confirmed that $\mathrm{Hg}^{0}$ was oxidized to $\mathrm{HgO}$ by $\mathrm{Co}_{3} \mathrm{O}_{4} @ \mathrm{C}$. 

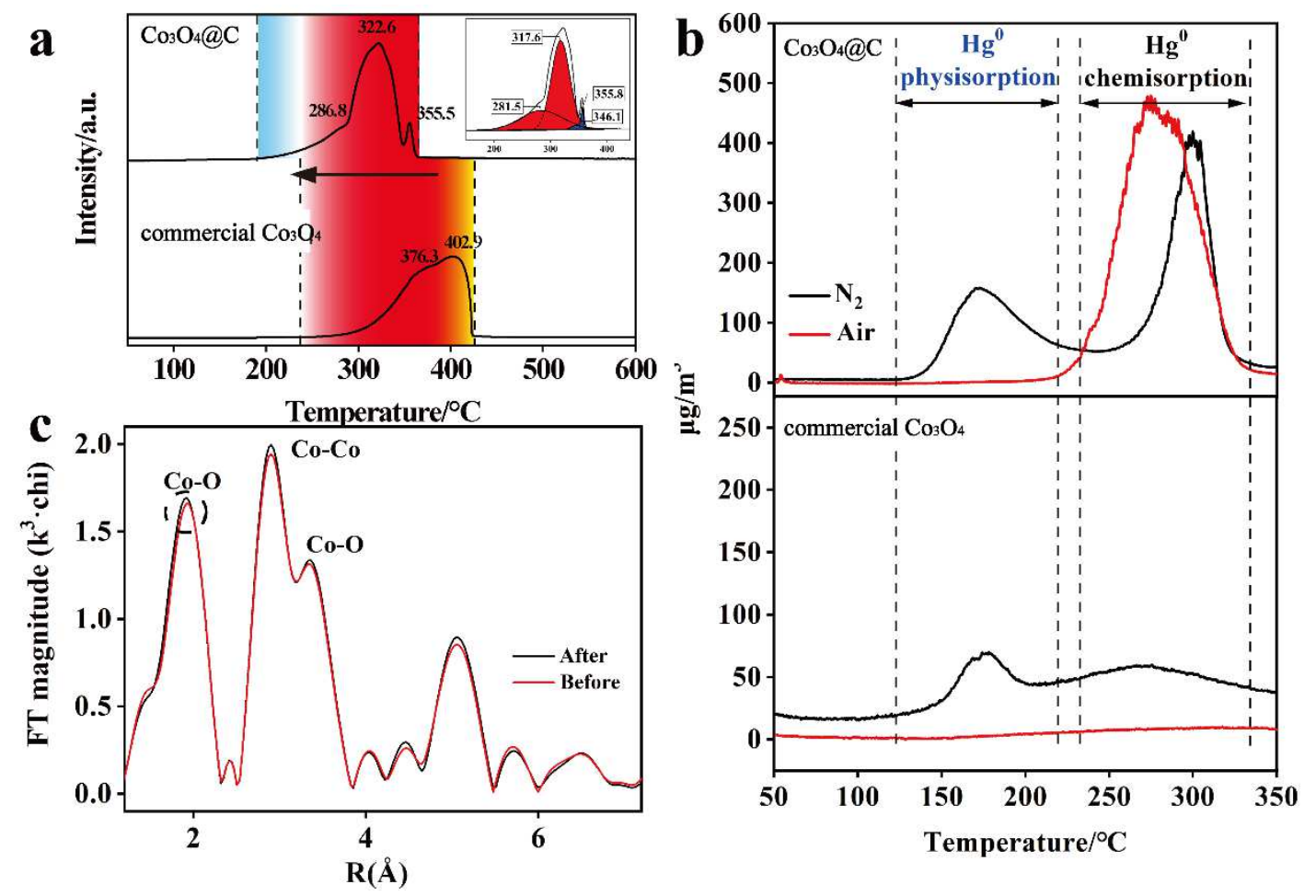

322 Figure 6. (a) $\mathrm{H}_{2}$-TPR spectra of $\mathrm{Co}_{3} \mathrm{O}_{4} @ \mathrm{C}$ and commercial $\mathrm{Co}_{3} \mathrm{O}_{4}$; (b) $\mathrm{Hg}$-TPD spectra of $323 \mathrm{Co}_{3} \mathrm{O}_{4} @ \mathrm{C}$ and commercial $\mathrm{Co}_{3} \mathrm{O}_{4} ;$; (c) Extended $\mathrm{X}$-ray adsorption fine structure-Fourier 324 transform (EXAFS-FT) of $\mathrm{Co}_{3} \mathbf{O}_{4} @ \mathbf{C}$ before and after $\mathbf{H g}^{\mathbf{0}}$ removal. surface of $\mathrm{Co}_{3} \mathrm{O}_{4}$ also played an important role in $\mathrm{Hg}^{0}$ oxidation. When there was no $\mathrm{O}_{2}$ in 327 the carrier gas, the lattice oxygen on the surface of $\mathrm{Co}_{3} \mathrm{O}_{4} @ \mathrm{C}$ could be activated and 328 reacted with $\mathrm{Hg}^{0}$ as the ambient temperature rose from $25^{\circ} \mathrm{C}$ to $150{ }^{\circ} \mathrm{C}$, resulting in an 329 increase in deactivation time of $\mathrm{Co}_{3} \mathrm{O}_{4} @ \mathrm{C}$ (the orange line in Figure 3a). $\mathrm{H}_{2}-\mathrm{TPR}$ was 330 conducted to explore the $\mathrm{Co}-\mathrm{O}$ bond strength difference between commercial $\mathrm{Co}_{3} \mathrm{O}_{4}$ and $331 \mathrm{Co}_{3} \mathrm{O}_{4} @ \mathrm{C}$ in this study. Its data was revealed in Figure 6a. The peaks of commercial $\mathrm{Co}_{3} \mathrm{O}_{4}$ at $376.3^{\circ} \mathrm{C}$ and $402.9{ }^{\circ} \mathrm{C}$ were related to the reduction of $\mathrm{Co}_{3} \mathrm{O}_{4}$ to $\mathrm{CoO}$ and $\mathrm{CoO}$ to $\mathrm{Co}$, 333 respectively. The $\mathrm{H}_{2}$-TPR spectra of $\mathrm{Co}_{3} \mathrm{O}_{4} @ \mathrm{C}$ could be divided into two parts (inset of 334 Figure 6a). It had two small reduction peaks at $346.1^{\circ} \mathrm{C}$ and $355.8^{\circ} \mathrm{C}$, and this might be 
335 due to the presence of bulk $\mathrm{Co}_{3} \mathrm{O}_{4}$. Its main reduction peaks were at $281.5^{\circ} \mathrm{C}$ and $317.6^{\circ} \mathrm{C}$.

336 The reduction temperatures of $\mathrm{Co}_{3} \mathrm{O}_{4} @ \mathrm{C}$ were lower than those of commercial $\mathrm{Co}_{3} \mathrm{O}_{4}$, 337 showing the weaker $\mathrm{Co}-\mathrm{O}$ bond strength in $\mathrm{Co}_{3} \mathrm{O}_{4} @ \mathrm{C}$. The lattice oxygen on the surface 338 of $\mathrm{Co}_{3} \mathrm{O}_{4} @ \mathrm{C}$ was easier to be activated, which means that the temperature required for the 339 lattice oxygen activation of $\mathrm{Co}_{3} \mathrm{O}_{4} @ \mathrm{C}$ is lower, and it has more activated lattice oxygen 340 than commercial $\mathrm{Co}_{3} \mathrm{O}_{4}$ at the same temperature. This makes $\mathrm{Co}_{3} \mathrm{O}_{4} @ \mathrm{C}$ perform better 341 than commercial $\mathrm{Co}_{3} \mathrm{O}_{4}$ in $\mathrm{Hg}^{0}$ removal and shifts the $\mathrm{Hg}^{0}$ removal temperature window of $342 \mathrm{Co}_{3} \mathrm{O}_{4} @ \mathrm{C}$ to the low-temperature range.

343 The deactivation of $\mathrm{Co}_{3} \mathrm{O}_{4} @ \mathrm{C}$ was observed as the ambient temperature increased. 344 When the temperature exceeded $200{ }^{\circ} \mathrm{C}$, the $\mathrm{Hg}^{0}$ removal efficiency of $\mathrm{Co}_{3} \mathrm{O}_{4} @ \mathrm{C}$ dropped 345 sharply. Hg-TPD experiment could help to explain this phenomenon. Use the sample to 346 remove $\mathrm{Hg}^{0}$ for one hour in a $4 \% \mathrm{O}_{2}$ atmosphere. Then cut off the $\mathrm{Hg}^{0}$ source and heat the 347 sample in $\mathrm{N}_{2}$ or air. The temperature range is from $50{ }^{\circ} \mathrm{C}$ to $350{ }^{\circ} \mathrm{C}$ with a heating rate of $348 \quad 1^{\circ} \mathrm{C} /$ min. Figure $6 \mathrm{~b}$ showed the Hg-TPD spectra of $\mathrm{Co}_{3} \mathrm{O}_{4} @ \mathrm{C}$. It had two $\mathrm{Hg}^{0}$ thermal349 desorption peaks around $175^{\circ} \mathrm{C}$ and $275^{\circ} \mathrm{C}$ when the carrier gas was $\mathrm{N}_{2}$. When the carrier 350 gas changed from $\mathrm{N}_{2}$ to air, the peak around $175{ }^{\circ} \mathrm{C}$ disappeared. This peak could be 351 attributed to physically adsorbed $\mathrm{Hg}^{0}$ because physically adsorbed $\mathrm{Hg}^{0}$ could be oxidized 352 on the surface of $\mathrm{Co}_{3} \mathrm{O}_{4} @ \mathrm{C}$ in the presence of $\mathrm{O}_{2}$. Chemisorbed $\mathrm{Hg}^{0}$ would not be affected 353 by $\mathrm{O}_{2}$. Thus, the $\mathrm{Hg}^{0}$ thermal-desorption peak around $275^{\circ} \mathrm{C}$ did not disappear when the 354 carrier gas changed from $\mathrm{N}_{2}$ to air. In summary, the $\mathrm{Hg}^{0}$ thermal-desorption peaks around $355175^{\circ} \mathrm{C}$ and $275^{\circ} \mathrm{C}$ corresponded to physically adsorbed $\mathrm{Hg}^{0}$ and chemically adsorbed $\mathrm{Hg}^{0}$, 356 respectively.(Yang et al., 2014) It can be seen that the adsorption of $\mathrm{Hg}^{0}$ onto the surface 357 of $\mathrm{Co}_{3} \mathrm{O}_{4} @ \mathrm{C}$ would be inhibited when the temperature exceeded $175{ }^{\circ} \mathrm{C}$, and this 
358 temperature was the starting point for the decline in $\mathrm{Hg}^{0}$ removal performance of $\mathrm{Co}_{3} \mathrm{O}_{4} @ \mathrm{C}$.

359 Thus, $\mathrm{Hg}^{0}$ adsorption is one of the key steps for the catalyst to oxidize $\mathrm{Hg}^{0}$.

360 The analyses of the extended X-ray absorption fine structure (EXAFS) spectrum allowed 361 to determine the atomic structure and the coordinating environment of Co in the sample 362 accurately. This technique helped to analyze the stability of the catalyst during $\mathrm{Hg}^{0}$ removal. 363 Figure 6c showed the EXAFS Fourier transform (FT) of $\mathrm{Co}_{3} \mathrm{O}_{4} @ \mathrm{C}$ before and after $\mathrm{Hg}^{0}$ 364 removal. It revealed three main peaks located at $1.90 \AA, 2.85 \AA$, and $3.35 \AA$ which 365 corresponded to $\mathrm{Co}-\mathrm{O}, \mathrm{Co}-\mathrm{Co} 1$, and $\mathrm{Co}-\mathrm{Co} 2$ coordination, respectively. The spectrum 366 showed that there was no obvious peak shift of the sample observed after $\mathrm{Hg}^{0}$ removal, 367 indicating the great structure stability of $\mathrm{Co}_{3} \mathrm{O}_{4} @ \mathrm{C}$ during $\mathrm{Hg}^{0}$ removal.

368 The mechanism of $\mathrm{Hg}^{0}$ oxidation by $\mathrm{Co}_{3} \mathrm{O}_{4} @ \mathrm{C}$ is clear. Firstly, $\mathrm{Hg}^{0}$ was adsorbed on 369 the surface of the sample, and then it was oxidized to $\mathrm{HgO}$ by activated $\mathrm{O}_{2}$ or the lattice 370 oxygen of $\mathrm{Co}_{3} \mathrm{O}_{4} @ \mathrm{C}$. This was in line with the Mars-Maessen mechanism that $\mathrm{Hg}^{0}$ needs 371 to be adsorbed onto the surface of the catalyst before it is oxidized,(Presto and Granite, 372 2006) and the reactions could be described as following.(Liu et al., 2011; Yang et al., 2014)

$$
\begin{gathered}
\mathrm{Hg}(\mathrm{g}) \rightarrow \mathrm{Hg}(\text { ads }) \\
\mathrm{Hg}(\text { ads })+\mathrm{Co}_{\mathrm{x}} \mathrm{O}_{\mathrm{y}} \rightarrow \mathrm{HgO}(\text { ads })+\mathrm{Co}_{\mathrm{x}} \mathrm{O}_{\mathrm{y}-1} \\
\mathrm{Co}_{\mathrm{x}} \mathrm{O}_{\mathrm{y}-1}+\frac{1}{2} \mathrm{O}_{2} \rightarrow \mathrm{Co}_{\mathrm{x}} \mathrm{O}_{\mathrm{y}}
\end{gathered}
$$



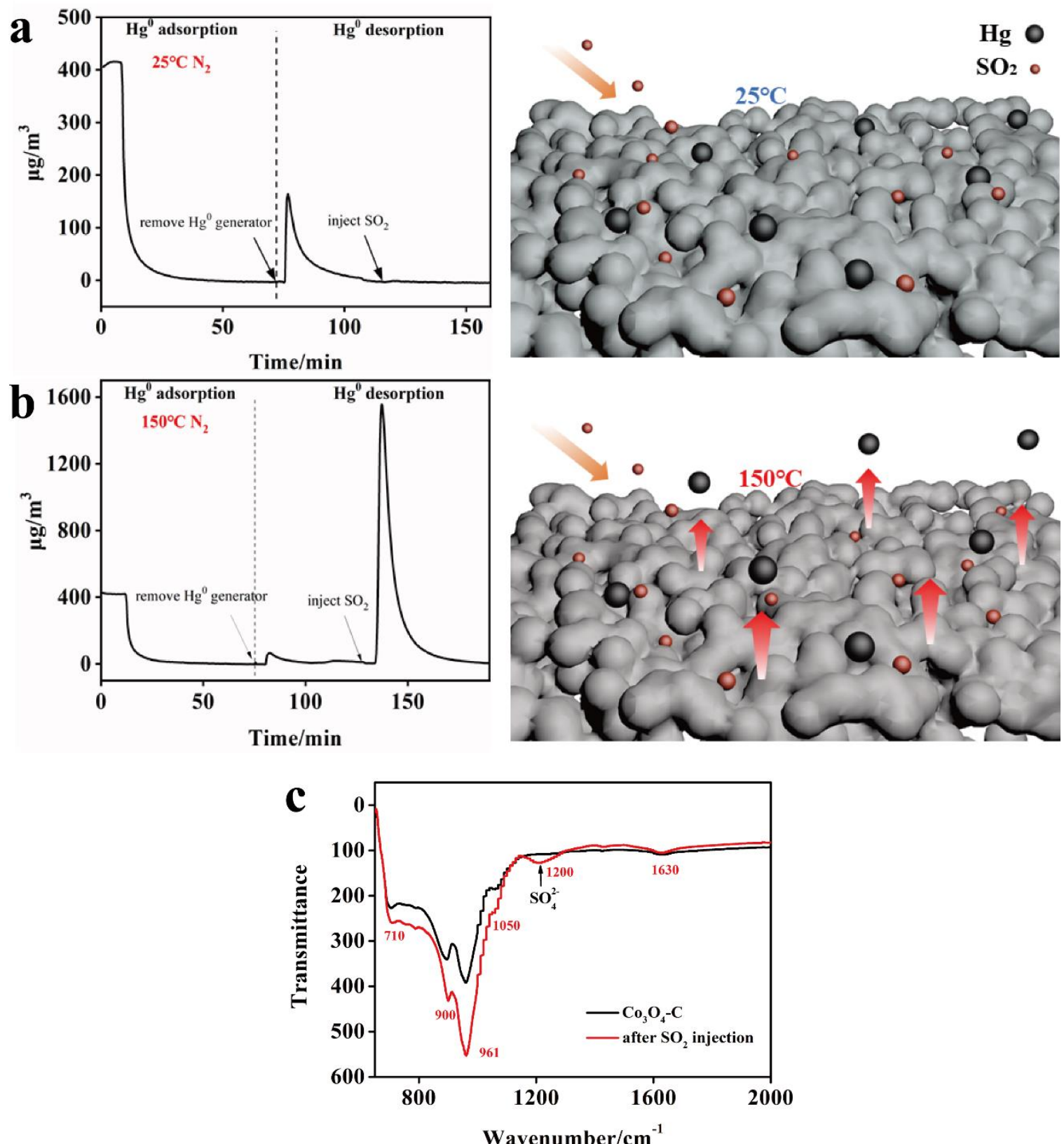

380 Figure 7. (a-b) $\mathbf{H g}^{\mathbf{0}}$ adsorption and desorption experiments and their mechanism simulation diagram. Experimental temperature (a) $25^{\circ} \mathrm{C}$; (b) $150^{\circ} \mathrm{C}$. Experimental conditions: catalyst mass, $50 \mathrm{mg}$; gas stream contents, $\mathrm{N}_{2} \rightarrow 2286 \mathrm{mg} / \mathrm{m}^{3} \mathrm{SO}_{2}+\mathrm{N}_{2}$; gas flow rate, $100 \mathrm{~mL} / \mathrm{min}$. (c) the FT-IR spectra of $\mathrm{Co}_{3} \mathrm{O}_{4} @ \mathrm{C}$ before and after $\mathrm{SO}_{2}$ injection.

In this work, $\mathrm{SO}_{2}$ did not show the inhibition of the $\mathrm{Hg}^{0}$ removal efficiency of $\mathrm{Co}_{3} \mathrm{O}_{4} @ \mathrm{C}$ at room temperature. A new experiment was introduced to find out its mechanism, and its setting was as follows. Firstly, the sample $\mathrm{Co}_{3} \mathrm{O}_{4} @ \mathrm{C}$ adsorbed $\mathrm{Hg}^{0}$ for an hour in pure $\mathrm{N}_{2}$ 
at $25^{\circ} \mathrm{C}$ or $150{ }^{\circ} \mathrm{C}$. Then the $\mathrm{Hg}^{0}$ generator was removed, and $2286 \mathrm{mg} / \mathrm{m}^{3} \mathrm{SO}_{2}$ was injected into the gas flow. The result was shown in Figure 7a-7b.

A peak of $\mathrm{Hg}^{0}$ desorption immediately appeared as $\mathrm{SO}_{2}$ entered in Figure $7 \mathrm{~b}$, proving that there was a competitive adsorption relationship between $\mathrm{SO}_{2}$ and $\mathrm{Hg}^{0}$ at $150{ }^{\circ} \mathrm{C}$. This explained why $\mathrm{SO}_{2}$ inactivated the sample $\mathrm{Co}_{3} \mathrm{O}_{4} @ \mathrm{C}$ at high temperatures. Obviously, $\mathrm{SO}_{2}$ was more competitive than $\mathrm{Hg}^{0}$. It could occupy adsorption sites and combine with lattice oxygen on the surface of the sample $\mathrm{Co}_{3} \mathrm{O}_{4} @ \mathrm{C}$. This suppressed the occurrence of equation (2), and the subsequent oxidation reactions cannot occur, resulting in a reduction in the $\mathrm{Hg}^{0}$ removal performance of the sample. Nevertheless, when the experimental temperature was adjusted to $25{ }^{\circ} \mathrm{C}$, there was no $\mathrm{Hg}^{0}$ desorption peak observed with the influx of $\mathrm{SO}_{2} . \mathrm{Hg}^{0}$ was not driven away from the surface of the sample by $\mathrm{SO}_{2}$ at room temperature, indicating that $\mathrm{SO}_{2}$ did not compete with $\mathrm{Hg}^{0}$ at room temperature. As mentioned before, the deactivated time of $\mathrm{Co}_{3} \mathrm{O}_{4} @ \mathrm{C}$ in the $\mathrm{SO}_{2}+\mathrm{N}_{2}$ atmosphere is almost the same as that in the $\mathrm{O}_{2}+\mathrm{N}_{2}$ atmosphere at $25^{\circ} \mathrm{C}$. Both $\mathrm{SO}_{2}$ and $\mathrm{O}_{2}$ could improve the $\mathrm{Hg}^{0}$ removal performance of the sample independently. The reason for the promotion is due to the generation of $\mathrm{SO}_{3}$ by $\mathrm{SO}_{2}$ oxidation on the sample.(Li et al., 2017b) FT-IR analysis corroborated this view. The FT-IR spectra of the sample before and after injection of $\mathrm{SO}_{2}$ (Figure 7c) indicated the generation of sulfates in $\mathrm{Co}_{3} \mathrm{O}_{4} @ \mathrm{C}$ during the experiment. The band that appeared around $1200 \mathrm{~cm}^{-1}$ could be ascribed to the sulfates located in the bulk or subsurface of metal oxides.(Zhang et al., 2015) Consequently, $\mathrm{SO}_{2}$ was converted to $\mathrm{SO}_{4}{ }^{2-}$ on the surface of the sample during the experiment.

In summary, $\mathrm{SO}_{2}$ was oxidized to $\mathrm{SO}_{3}$ on the surface of $\mathrm{Co}_{3} \mathrm{O}_{4} @ \mathrm{C}$ and then oxidizes the adsorbed $\mathrm{Hg}^{0}$. The reactions could be described as following.(Zhang et al., 2020a) 


$$
\mathrm{Co}_{\mathrm{x}} \mathrm{O}_{\mathrm{y}}+\mathrm{SO}_{2} \rightarrow \mathrm{Co}_{\mathrm{x}} \mathrm{O}_{\mathrm{y}-1} \cdot \mathrm{SO}_{3}
$$

$$
\mathrm{Co}_{\mathrm{x}} \mathrm{O}_{\mathrm{y}-1} \cdot \mathrm{SO}_{3}+\mathrm{Hg}(\text { ads }) \rightarrow \mathrm{Co}_{\mathrm{x}} \mathrm{O}_{\mathrm{y}-1}+\mathrm{HgSO}_{3}(\text { ads })
$$

When $\mathrm{O}_{2}$ appeared in the carrier gas, equation (9) and (10) happened and lattice oxygen got

416 replenishment.

\section{Conclusions}

418 The $\mathrm{Co}_{3} \mathrm{O}_{4} @ \mathrm{C}$ composite material formed by burning the sacrificial template Co-BDC 419 showed excellent $\mathrm{Hg}^{0}$ removal capability and strong $\mathrm{SO}_{2}$ resistance at ambient temperature. 420 Its temperature window shifted to a low-temperature range compared to traditional $\mathrm{Co}_{3} \mathrm{O}_{4}$ 421 catalysts. Meanwhile, it was found that the competition between $\mathrm{SO}_{2}$ and $\mathrm{Hg}^{0}$ on the 422 surface of $\mathrm{Co}_{3} \mathrm{O}_{4}$ disappeared, and $\mathrm{SO}_{2}$ participated in the oxidation of $\mathrm{Hg}^{0}$ at ambient 423 temperature. The role of $\mathrm{SO}_{2}$ in $\mathrm{Hg}^{0}$ removal was discussed. This is a great improvement 424 to the application of $\mathrm{Co}_{3} \mathrm{O}_{4}$ in $\mathrm{Hg}^{0}$ removal. It reduces the restrictions on the use of $\mathrm{Co}_{3} \mathrm{O}_{4}$ 425 in $\mathrm{Hg}^{0}$ removal. $\mathrm{Co}_{3} \mathrm{O}_{4} @ \mathrm{C}$ showed great adaptability to the complex simulated flue gas at 426 ambient temperature.

428 Availability of data and materials: All data generated or analyzed during this study are 429 included in this published article. 
430 Authors' contributions: All authors (Jiacheng Zhou, Qicheng Shen, Jie Yang, 431 Muhammad Tariq, Wei Sun, Limei Cao and Ji Yang) read and approved the final 432 manuscript.

\section{Declarations}

434 Funding: This research is based on the work supported by the National Natural Science 435 Foundation of China (Project No.51778229, 21307032) and the Fundamental Research 436 Funds for the Central Universities (Project No. JKB012015019).

437 Ethics approval: Since this study did not recruit any human and/or animal subjects, this 438 section does not apply.

439 Consent to participate: Not applicable.

440 Consent for publication: The authors confirm that the final version of the manuscript has 441 been reviewed, approved, and consented for publication by all authors.

442 Competing interests: The authors declare that we have no financial and personal 443 relationships with other people or organizations that can inappropriately influence the work 444 reported in this paper. 


\section{References}

447 Bisson T M, Xu Z (2015). Potential Hazards of Brominated Carbon Sorbents for Mercury

448 Emission Control. Environmental Science \& Technology, 49(4): 2496-2502

449 doi:10.1021/es5052793

450 Cao T, Li Z, Xiong Y, Yang Y, Xu S, Bisson T, Gupta R, Xu Z (2017). Silica-Silver 451 Nanocomposites as Regenerable Sorbents for $\mathrm{Hg}(0)$ Removal from Flue Gases. Environmental 452 Science \& Technology, 51(20): 11909-11917 doi:10.1021/acs. est. 7b01701

453 Chen W, Han B, Tian C, Liu X, Liang S, Deng H, Lin Z (2019). MOFs-derived ultrathin 454 holey Co304 nanosheets for enhanced visible light C02 reduction. Applied Catalysis B455 Environmental, 244: 996-1003 doi:10. 1016/j. apcatb. 2018. 12.045

456 Cheng T, Zhou X, Yang L, Wu H, Fan H (2020). Transformation and removal of ammonium 457 sulfate aerosols and ammonia slip from selective catalytic reduction in wet flue gas desulfurization system. Journal of Environmental Sciences, 88: 72-80 doi:10. 1016/j. jes. 2019.08. 002

460 Dai E, Xu J, Qiu J, Liu S, Chen P, Liu Y (2017). Co@Carbon and Co 3 04@Carbon 461 nanocomposites derived from a single MOF for supercapacitors. Sci Rep, 7(1): 12588 doi:10. 1038/s41598-017-12733-5 Hu Z, Li K, Wu X, Wang N, Li X, Li Q, Li L, Lv K (2019). Dramatic promotion of visiblelight photoreactivity of Ti02 hollow microspheres towards N0 oxidation by introduction of oxygen vacancy. Applied Catalysis B: Environmental, 256

466 doi:10.1016/j. apcatb. 2019. 117860 Ji G, George A, Skoulou V, Reed G, Millan M, Hooman K, Bhatia S K, Diniz Da Costa J C (2018). Investigation and simulation of the transport of gas containing mercury in microporous silica membranes. Chemical Engineering Science, 190: 286-296 doi:10. 1016/j. ces. 2018.06. 006 Jin R, Liu Y, Wu Z, Wang H, Gu T (2010). Low-temperature selective catalytic reduction of NO with $\mathrm{NH}(3)$ over Mn-Ce oxides supported on Ti02 and A1203: a comparative study. Chemosphere, 78(9): 1160-1166 doi:10.1016/j. chemosphere. 2009.11. 049

474 Li H, Wu C-Y, Li Y, Zhang J (2011). Ce02-Ti02 Catalysts for Catalytic 0xidation of 475 Elemental Mercury in Low-Rank Coal Combustion Flue Gas. Environmental Science \& 476 Technology, 45(17): 7394-7400 doi:10. 1021/es2007808

477 Li H, Wu C Y, Li Y, Li L, Zhao Y, Zhang J (2012). Role of flue gas components in mercury 478 oxidation over Ti02 supported Mn0x-Ce02 mixed-oxide at low temperature. Journal of 479 Hazardous Materials, 243: 117-123 doi:10. 1016/j. jhazmat. 2012.10. 007

480 Li J, Chen W, Zhao H, Zheng X, Wu L, Pan H, Zhu J, Chen Y, Lu J (2017a). Size-dependent 481 catalytic activity over carbon-supported palladium nanoparticles in dehydrogenation of

482 formic acid. Journal of Catalysis, 352: 371-381 doi:10.1016/j. jcat.2017. 06. 007

483 Li Y, Duan Y, Wang H, Zhao S, Chen M, Liu M, Wei H (2017b). Effects of Acidic Gases on 484 Mercury Adsorption by Activated Carbon in Simulated 0xy-Fuel Combustion Flue Gas. Energy 485 \& Fuels, 31(9): 9745-9751 doi:10. 1021/acs. energyfuels. 7b01480

486 Li Y, Murphy P D, Wu C-Y, Powers K W, Bonzongo J-C J (2008). Development of 25 

silica/vanadia/titania catalysts for removal of elemental mercury from coal-combustion flue gas. Environmental Science \& Technology, 42(14): 5304-5309 doi:10.1021/es8000272 Liu Y (2008). Comment on "Impact of Sulfur 0xides on Mercury Capture by Activated Carbon". Environmental Science \& Technology, 42(3): 970-971 doi:10. 1021/es7021347 Liu Y, Wang Y, Wang H, Wu Z (2011). Catalytic oxidation of gas-phase mercury over Co/Ti02 catalysts prepared by sol-gel method. Catalysis Communications, 12(14): 1291-1294 doi: 10. 1016/j. catcom. 2011.04. 017 Machida M, Murata Y, Kishikawa K, Zhang D, Ikeue K (2008). On the reasons for high activity of $\mathrm{Ce} 02$ catalyst for soot oxidation. Chemistry of Materials, 20(13) : 4489-4494 doi:10. 1021/cm800832w Mochida I, Korai Y, Shirahama M, Kawano S, Hada T, Seo Y, Yoshikawa M, Yasutake A (2000). Removal of S0x and NOx over activated carbon fibers. Carbon, 38(2): 227-239 doi:10. 1016/s0008-6223 (99) 00179-7 Pacyna E G, Pacyna J M, Steenhuisen F, Wilson S (2006). Global anthropogenic mercury emission inventory for 2000. Atmospheric Environment, 40(22): 4048-4063 doi:10. 1016/j. atmosenv. 2006. 03. 041 Presto A A, Granite E J (2006). Survey of catalysts for oxidation of mercury in flue gas. Environmental Science \& Technology, 40(18) : 5601-5609 doi:10.1021/es060504i Shekhah 0, Liu J, Fischer R A, Woll C (2011). MOF thin films: existing and future applications. Chem Soc Rev, 40(2): 1081-1106 doi:10.1039/c0cs00147c Tao K, Han X, Cheng Q, Yang Y, Yang Z, Ma Q, Han L (2018). A Zinc Cobalt Sulfide Nanosheet Array Derived from a 2D Bimetallic Metal-Organic Frameworks for HighPerformance Supercapacitors. Chemistry, 24(48): 12584-12591 doi:10. 1002/chem. 201800960 Wei W, Chen W, Ivey D G (2008). Rock salt-spinel structural transformation in anodically electrodeposited Mn-Co-0 nanocrystals. Chemistry of Materials, 20(5): 1941-1947

513 Xu W, Hussain A, Liu Y (2018). A review on modification methods of adsorbents for 514 elemental mercury from flue gas. Chemical Engineering Journal, 346: 692-711 515 doi:10.1016/j. cej. 2018.03.049

516 Yang J, Zhao Y, Chang L, Zhang J, Zheng C (2015). Mercury Adsorption and Oxidation over 517 Cobalt 0xide Loaded Magnetospheres Catalyst from Fly Ash in 0xyfuel Combustion Flue Gas.

518 Environmental Science \& Technology, 49(13) : 8210-8218 doi:10.1021/acs. est. 5b01029

519 Yang J, Zhao Y, Zhang J, Zheng C (2014). Regenerable cobalt oxide loaded magnetosphere 520 catalyst from fly ash for mercury removal in coal combustion flue gas. Environmental 521 Science \& Technology, 48(24): 14837-14843 doi:10.1021/es504419v

522 Yang S, Guo Y, Yan N, Qu Z, Xie J, Yang C, Jia J (2011). Capture of gaseous elemental 523 mercury from flue gas using a magnetic and sulfur poisoning resistant sorbent Mn/gamma524 Fe203 at lower temperatures. Journal of Hazardous Materials, 186(1): 508-515 525 doi:10.1016/j. jhazmat.2010.11. 034

526 Yang W, Chen H, Han X, Ding S, Shan Y, Liu Y X (2020). Preparation of magnetic Co-Fe 527 modified porous carbon from agricultural wastes by microwave and steam activation for 
528 mercury removal. Journal of Hazardous Materials, 381: 10

529 doi:10.1016/j. jhazmat. 2019. 120981

530 Zhang A, Zheng W, Song J, Hu S, Liu Z, Xiang J (2014). Cobalt manganese oxides modified 531 titania catalysts for oxidation of elemental mercury at low flue gas temperature.

532 Chemical Engineering Journa1, 236: 29-38 doi:10. 1016/j. cej. 2013. 09. 060

533 Zhang H, Wang T, Zhang Y, Wang J, Sun B, Pan W-P (2020a). A review on adsorbent/catalyst 534 application for mercury removal in flue gas: Effect of sulphur oxides (S02, S03). Journal 535 of Cleaner Production, 276 doi:10. 1016/j. jclepro. 2020. 124220

536 Zhang L, Li L, Cao Y, Yao X, Ge C, Gao F, Deng Y, Tang C, Dong L (2015). Getting insight 537 into the influence of $\mathrm{S} 02$ on Ti02/Ce02 for the selective catalytic reduction of N0 by 538 NH3. Applied Catalysis B-Environmental, 165: 589-598 doi:10. 1016/j. apcatb. 2014. 10. 029

539 Zhang L X, Feng L P, Li P, Chen X, Jiang J T, Zhang S, Zhang C X, Zhang A C, Chen G F,

540 Wang H (2020b). Direct Z-scheme photocatalyst of hollow CoSx@CdS polyhedron constructed 541 by ZIF-67-templated one-pot solvothermal route: A signal-on photoelectrochemical sensor 542 for mercury (II). Chemical Engineering Journal, 395: 14 doi:10. 1016/j. cej. 2020.125072

543 Zhang X, Wang J, Tan B, Li Z, Cui Y, He G (2017). Ce-Co catalyst with high surface area 544 and uniform mesoporous channels prepared by template method for $\mathrm{Hg}-0$ oxidation. Catalysis 545 Communications, 98: 5-8 doi:10.1016/j. catcom. 2017.04. 024

546 Zhang X, Zhang H, Zhu H, Li C, Zhang N, Bao J, He G (2019a). Co304 Nanorods with a Great 547 Amount of 0xygen Vacancies for Highly Efficient Hg0 0xidation from Coal Combustion Flue 548 Gas. Energy \& Fuels, 33(7): 6552-6561 doi:10. 1021/acs. energyfuels. $9 b 00765$

549 Zhang X, Zhang H, Zhu H, Li C, Zhang N, Bao J, He G (2019b). Co304 Nanorods with a Great 550 Amount of 0xygen Vacancies for Highly Efficient Hg-0 0xidation from Coal Combustion Flue 551 Gas. Energy \& Fuels, 33 (7) : 6552-6561 doi:10. 1021/acs. energyfuels. 9b00765

552 Zhou J, Cao L, Wang Q, Tariq M, Xue Y, Zhou Z, Sun W, Yang J (2019). Enhanced Hg0 removal 553 via a-Mn02 anchored to MIL-96(A1). Applied Surface Science, 483: 252-259 554 doi:10.1016/j. apsusc. 2019.03. 261

555 
Figures
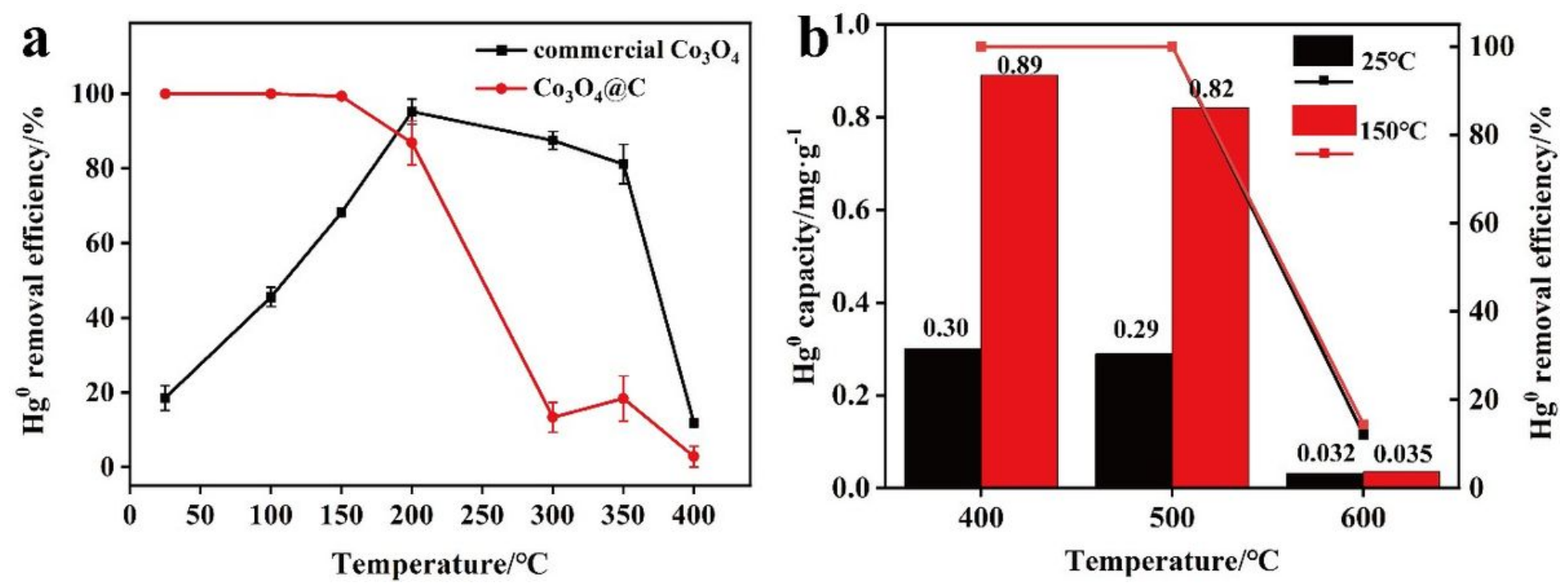

Figure 1

(a) Effect of temperature on Hg0 removal performance of commercial Co3O4 and Co3O4@C; (b) Effect of calcination temperature on $\mathrm{Hg} 0$ removal performance of Co304@C. 

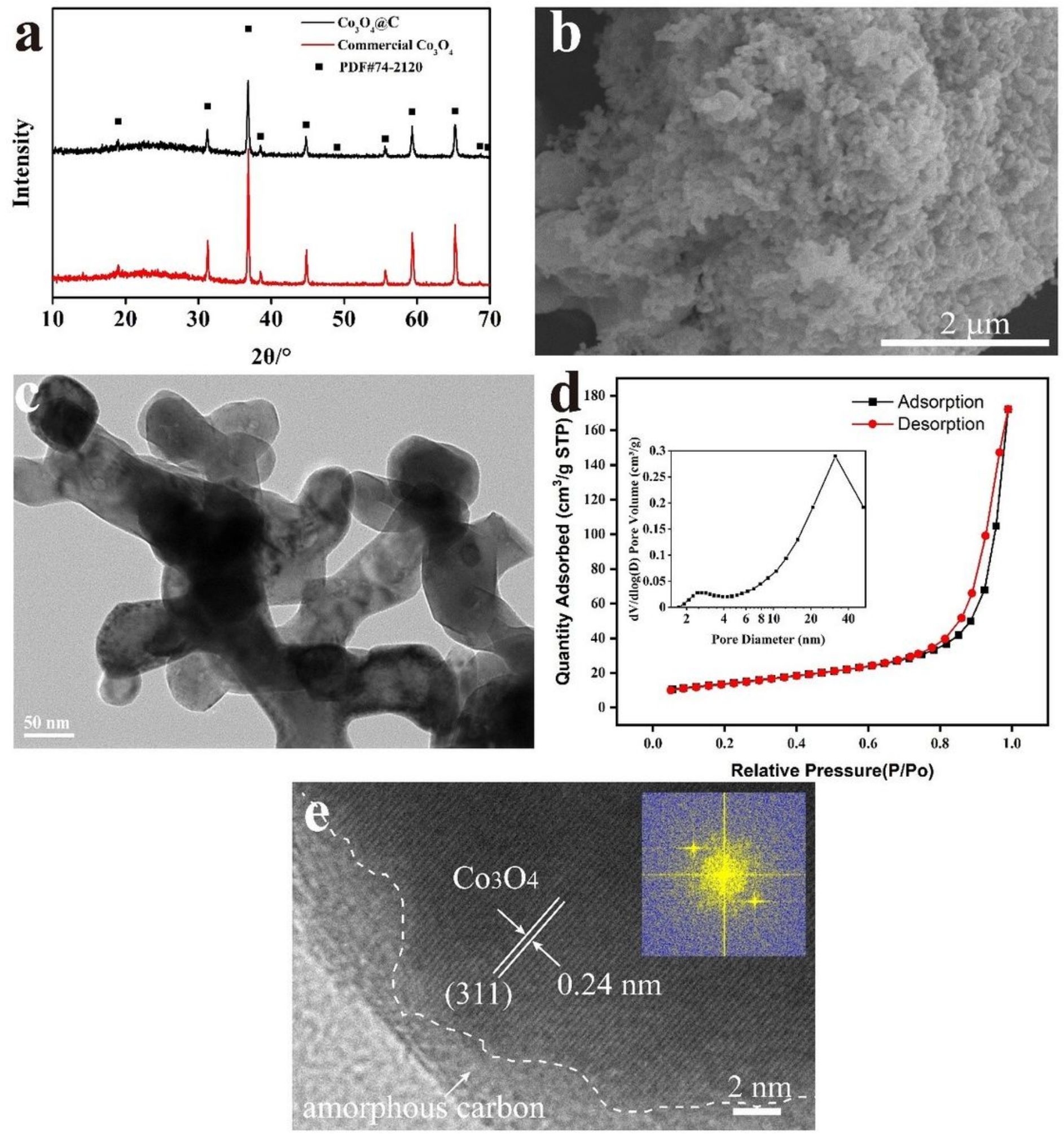

\section{Figure 2}

The micromorphology of Co304@C powders. (a) XRD patterns of Co304@C, commercial Co304, and the simulated Co304 (PDF\#74-2120) (b-c) SEM images of Co304@C powders prepared by the calcination method. (d) N2 adsorption-desorption isotherm of Co304@C and its pore size distribution. Inset shows the pore size distribution of the sample. (e) TEM image of Co304@C. 

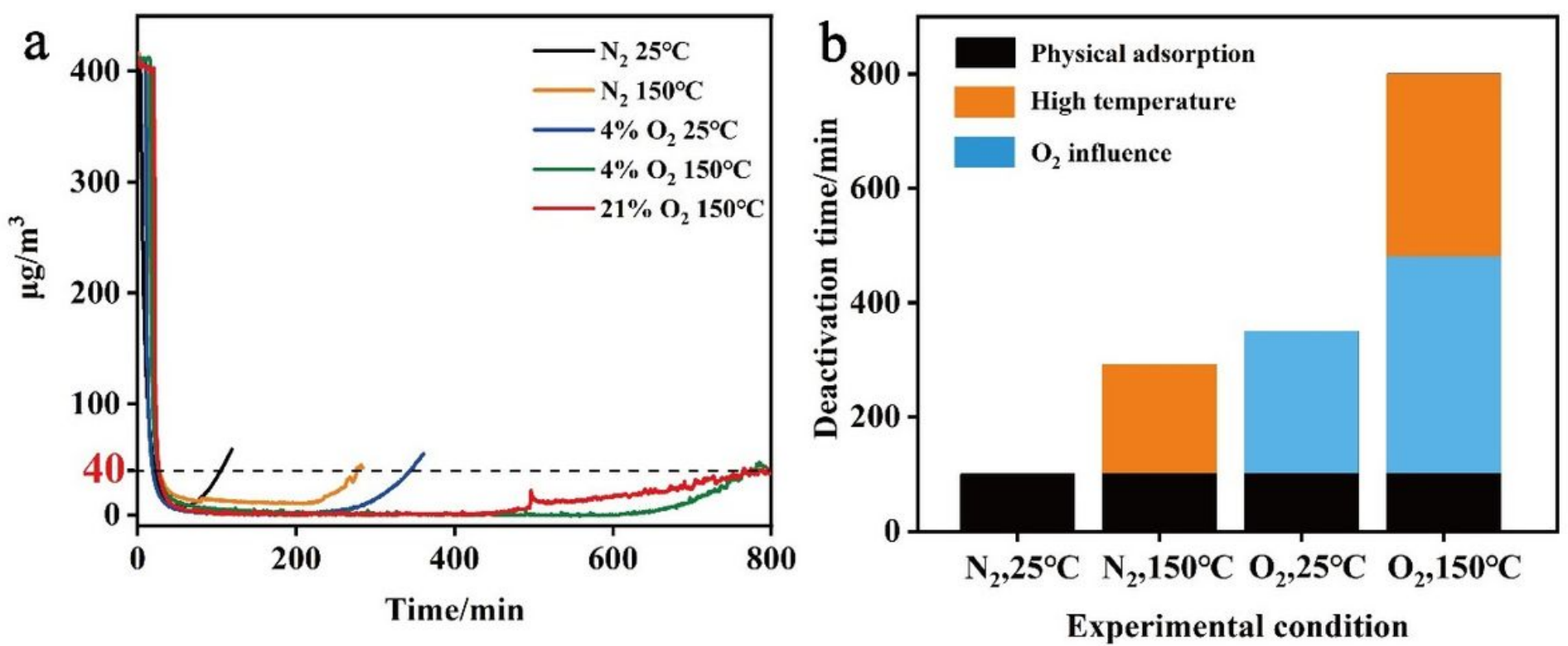

Figure 3

(a) The synergy of temperature and the gas components 02 on $\mathrm{Hg} 0$ removal performance of Co304@C.

(b) The analysis of different experimental conditions on deactivation time of Co304@C. 

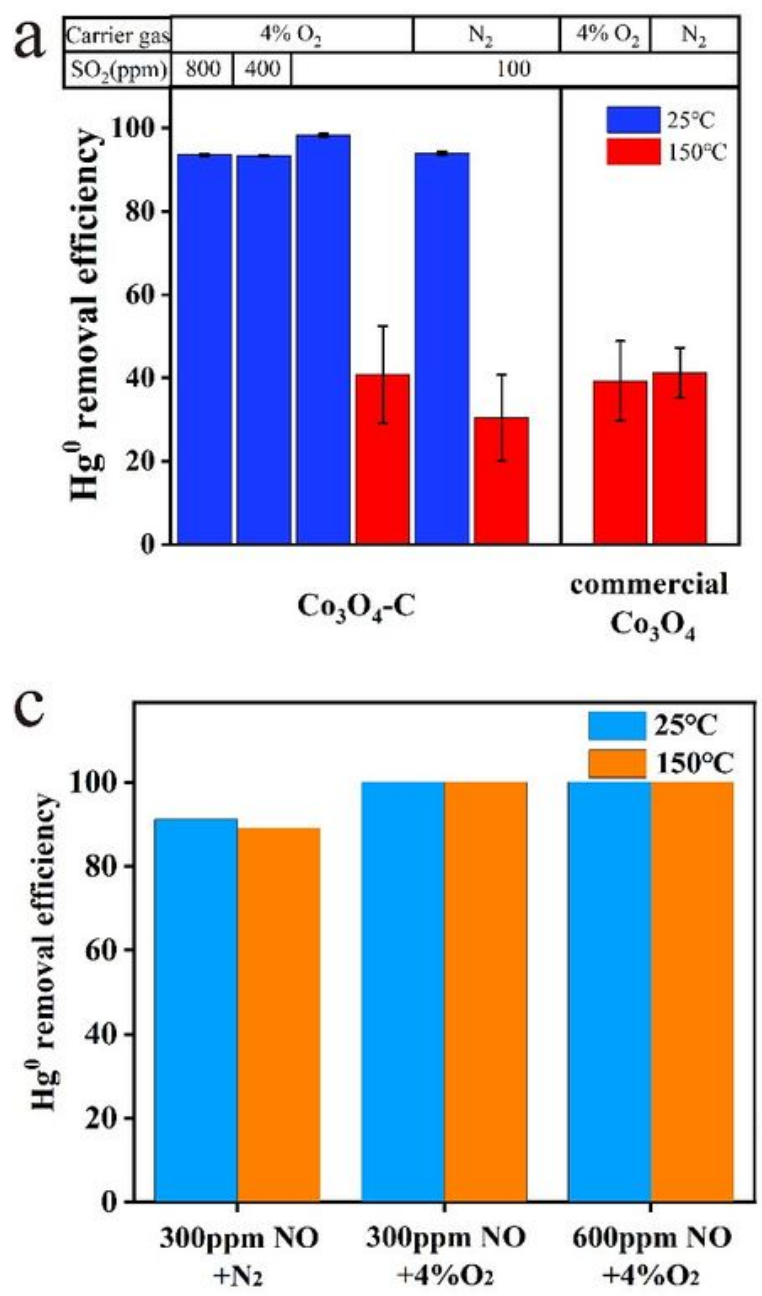

Gas composition
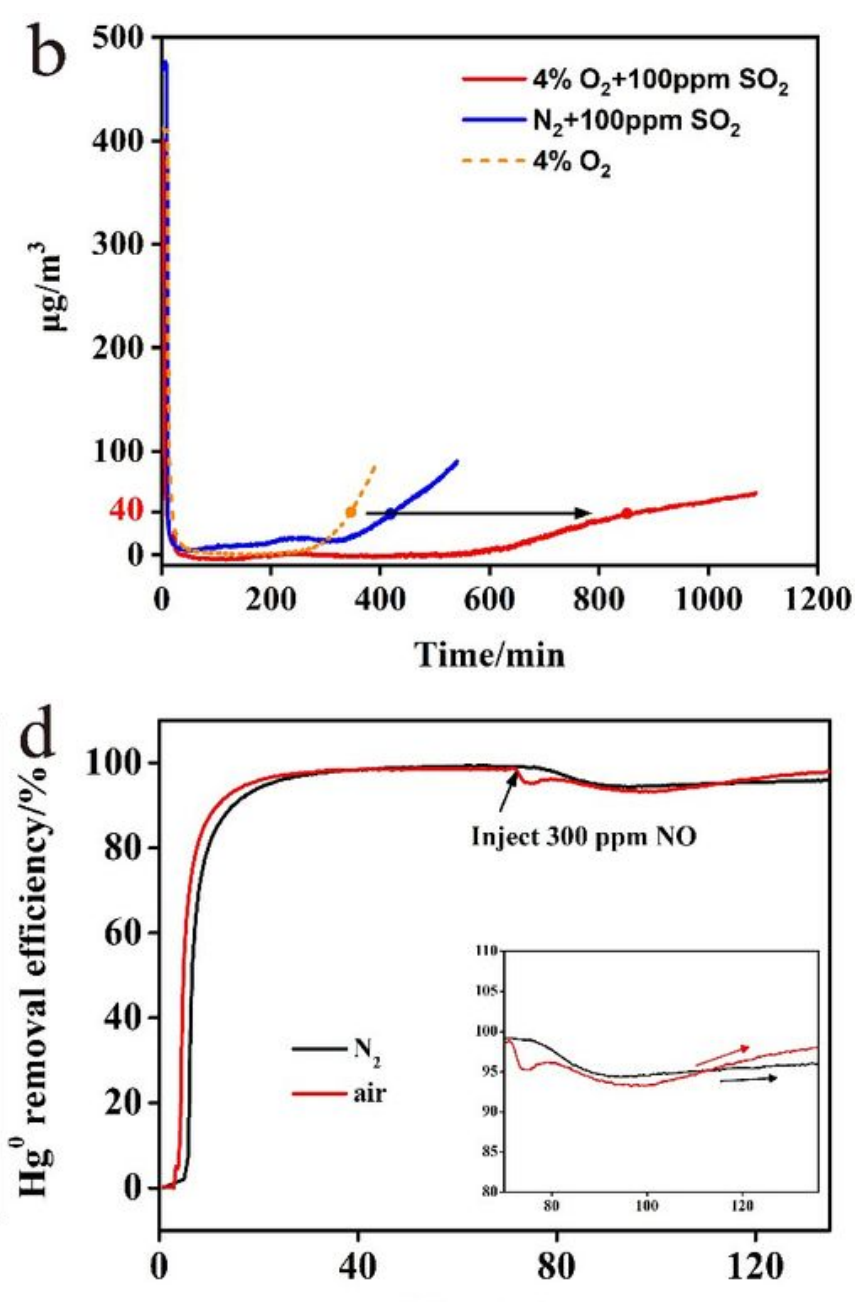

Time/min

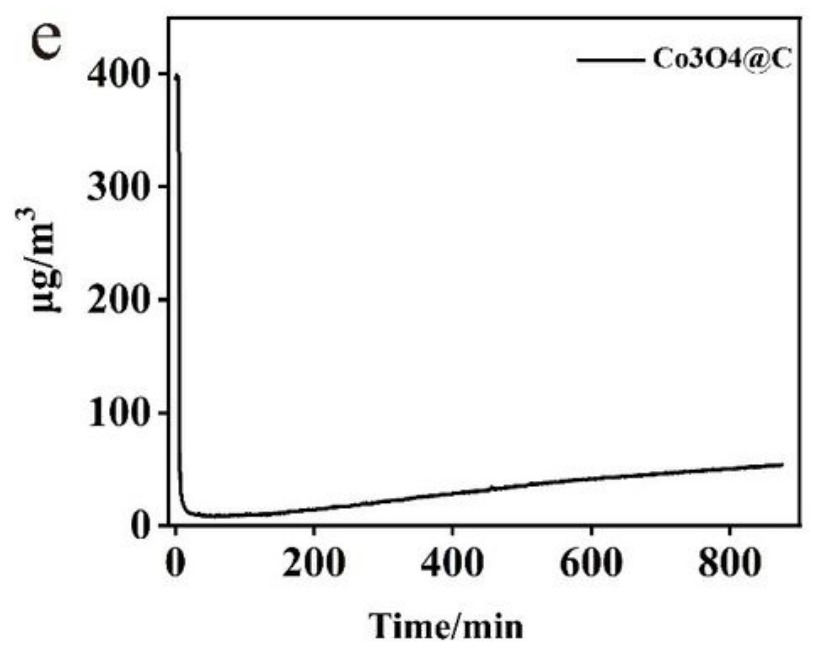

Figure 4

(a) Synergistic effect of temperature and $\mathrm{SO} 2$ on $\mathrm{HgO}$ removal efficiency of the sample. (b) Synergistic effect of $\mathrm{O} 2$ and $\mathrm{SO} 2$ on the deactivation time of the sample. Experimental conditions: catalyst mass, 50 mg; experimental temperature, 25 ॠ; gas stream contents, $285 \mathrm{mg} / \mathrm{m} 3 \mathrm{SO} 2+4 \%$ 02/N2; gas flow rate, 100 $\mathrm{mL} / \mathrm{min}$. (c) the effect of NOx on $\mathrm{HgO}$ removal efficiency. (d) the $\mathrm{HgO}$ removal performance. (e) The $\mathrm{HgO}$ 
removal performance of Co304@C in the simulate gas at ambient temperature. The gas components: $400 \mu \mathrm{g} / \mathrm{m} 3 \mathrm{Hg} 0+4 \% 02+2286$ mg/m3 SO2+402 mg/m3 NO+N2.
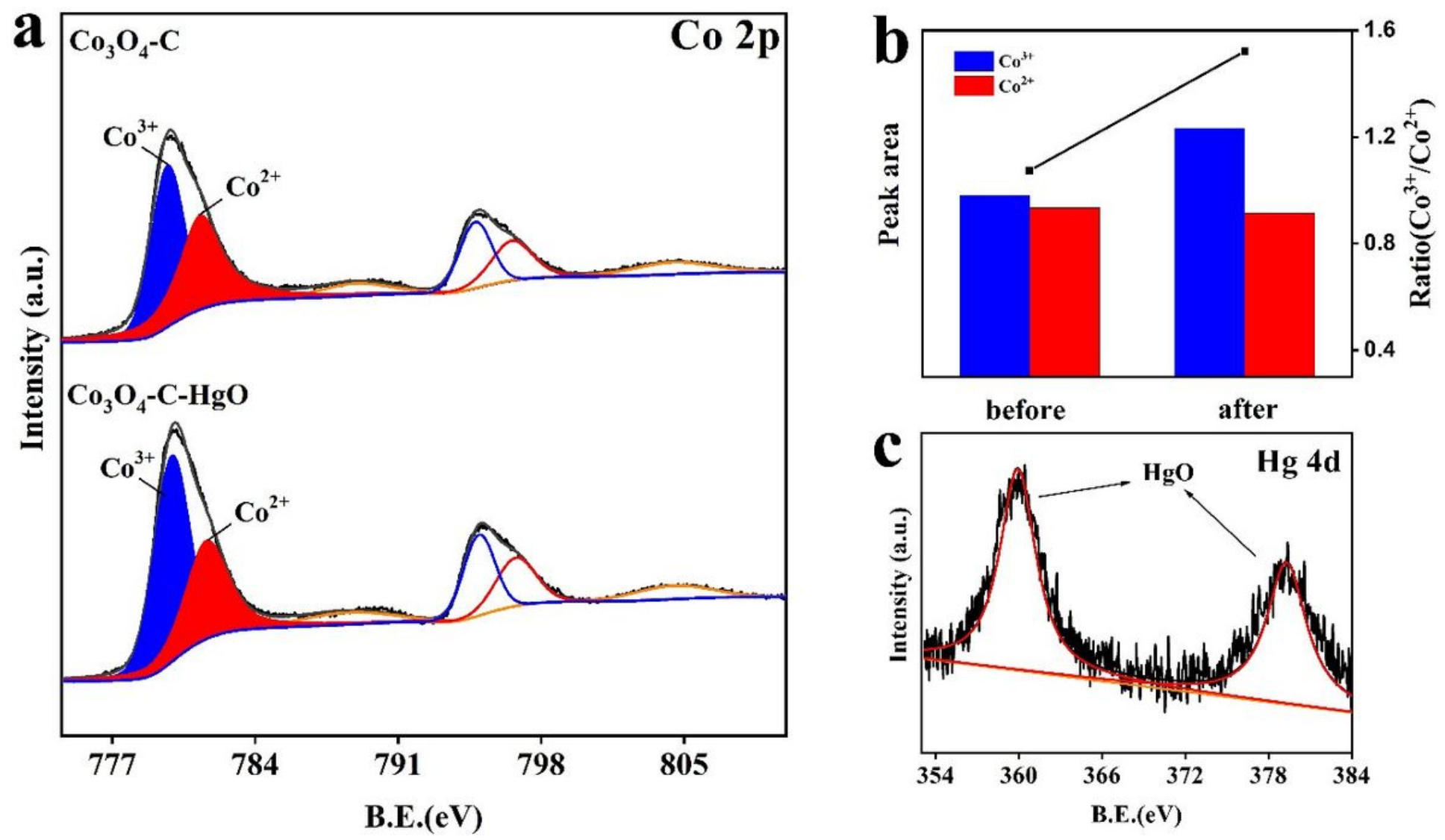

Figure 5

(a) The Co 2p XPS spectra of Co304@C before and after the treatment; (b) Peak area of Co 2p and the ratio change of $\mathrm{Co} 3+/ \mathrm{Co} 2+$. (c) The Hg 4d XPS spectra of Co304@C after the treatment. 

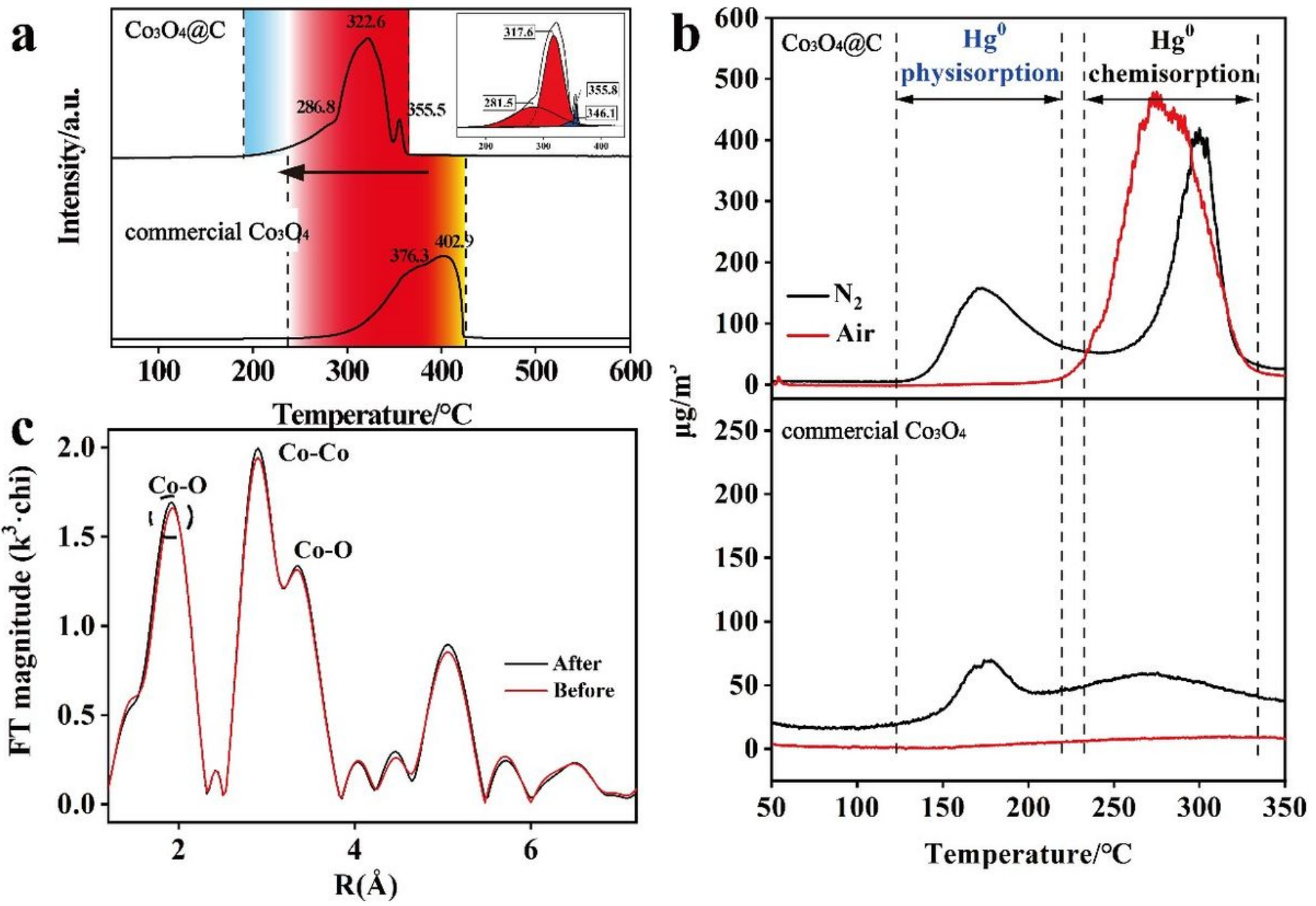

Figure 6

(a) H2-TPR spectra of Co304@C and commercial Co304; (b) Hg-TPD spectra of Co304@C and commercial Co304; (c) Extended X-ray adsorption fine structure-Fourier transform (EXAFS-FT) of Co304@C before and after $\mathrm{Hg} 0$ removal. 

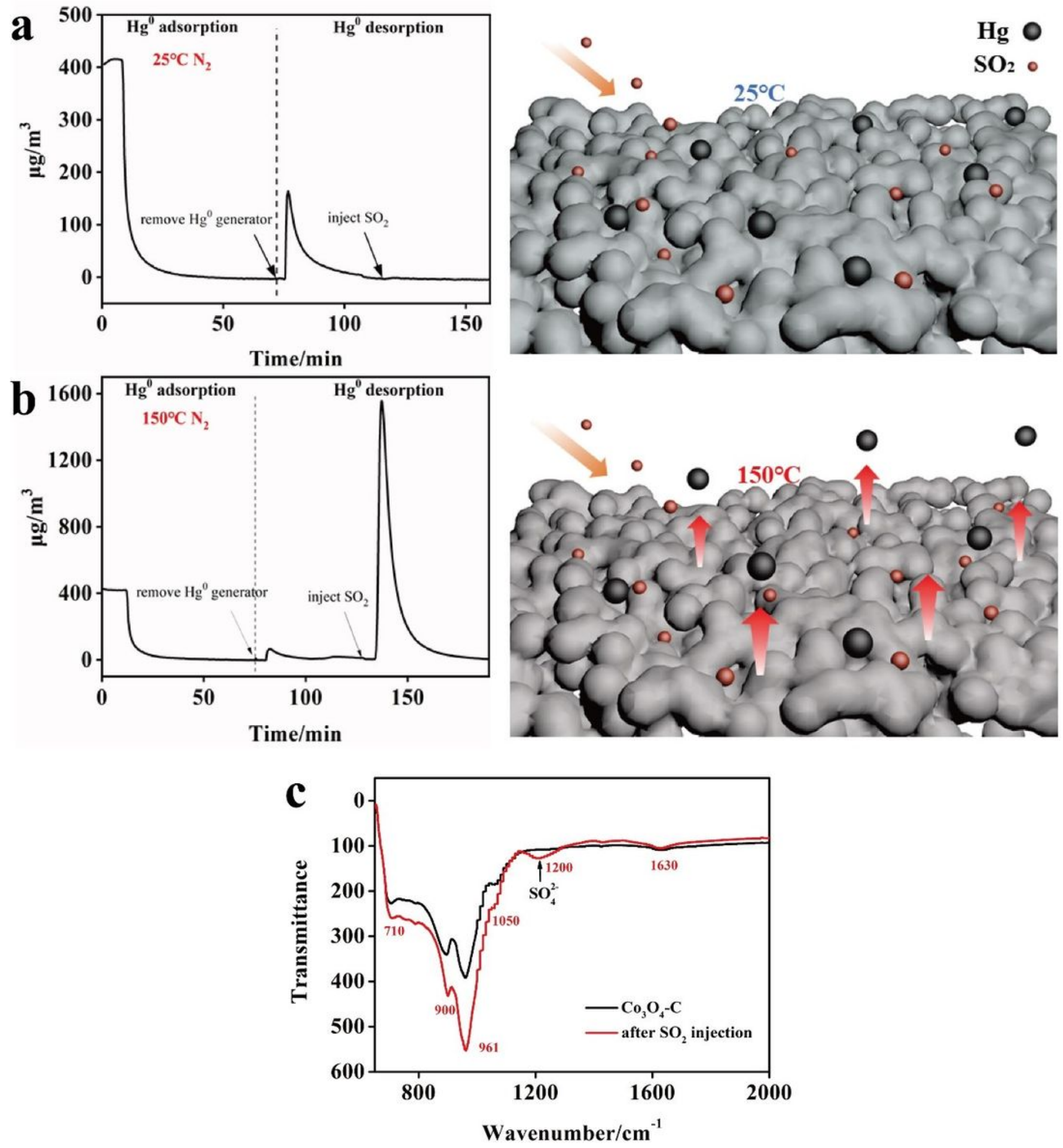

Figure 7

(a-b) $\mathrm{Hg} 0$ adsorption and desorption experiments and their mechanism simulation diagram. Experimental temperature (a) 25 ; (b) 150 \. Experimental conditions: catalyst mass, 50 mg; gas stream contents, N2 22286 mg/m3 S02+N2; gas flow rate, 100 mL/min. (c) the FT-IR spectra of Co304@C before and after SO2 injection. 